Atmos. Chem. Phys., 18, 17979-17994, 2018

https://doi.org/10.5194/acp-18-17979-2018

(C) Author(s) 2018. This work is distributed under

the Creative Commons Attribution 4.0 License.

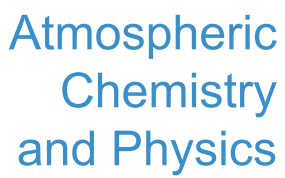

(c) (P)

\title{
High tropospheric ozone in Lhasa within the Asian summer monsoon anticyclone in 2013: influence of convective transport and stratospheric intrusions
}

\author{
Dan Li ${ }^{1,2}$, Bärbel Vogel ${ }^{1}$, Rolf Müller ${ }^{1}$, Jianchun Bian ${ }^{2,3}$, Gebhard Günther ${ }^{1}$, Qian $\mathbf{L i}^{2}$, Jinqiang Zhang ${ }^{2,3}$, \\ Zhixuan Bai ${ }^{2}$, Holger Vömel ${ }^{4}$, and Martin Riese ${ }^{1}$ \\ ${ }^{1}$ Institute of Energy and Climate Research: Stratosphere (IEK-7), Forschungszentrum Jülich, Jülich, Germany \\ ${ }^{2}$ Key Laboratory of Middle Atmosphere and Global Environment Observation (LAGEO), Institute of Atmospheric Physics, \\ Chinese Academy of Sciences, Beijing, China \\ ${ }^{3}$ College of Earth Science, University of Chinese Academy of Sciences, Beijing, China \\ ${ }^{4}$ Earth Observing Laboratory, National Center for Atmospheric Research, Boulder, CO, USA
}

Correspondence: Dan Li (da.li@fz-juelich.de) and Jianchun Bian (bjc@mail.iap.ac.cn)

Received: 28 June 2018 - Discussion started: 3 August 2018

Revised: 30 November 2018 - Accepted: 5 December 2018 - Published: 18 December 2018

\begin{abstract}
Balloon-borne measurements of ozone in Lhasa $\left(29.66^{\circ} \mathrm{N}, 91.14^{\circ} \mathrm{E} ; 3650 \mathrm{~m}\right.$ above sea level) in August 2013 are investigated using backward trajectory calculations performed with the Chemical Lagrangian Model of the Stratosphere (CLaMS). Measurements show three time periods characterized by high ozone mixing ratios (OMRs) in the troposphere on 8, 11, and 18-20 August 2013 during the Asian summer monsoon (ASM) season. Here, we verified two different sources for the enhanced ozone values in the troposphere. First, transport of polluted air from the boundary layer, and second downward transport from the stratosphere by stratospheric intrusions. Air pollution from South Asia through convective and long-range transport plays a key role in enhancing middle tropospheric OMRs up to $90 \%$ on 8 August and up to $125 \%$ on 11 August 2013 compared to monthly mean ozone of August 2013. Stratospheric air intruded from the northern high-latitudes to the southeastern flank of the ASM anticyclone to the troposphere and is identified as the source of enhanced ozone according to backward trajectory calculation and satellite measurements by the Ozone Monitoring Instrument (OMI) and the Atmospheric Infrared Sounder (AIRS). Air parcels with high ozone moved from the high-latitude lower stratosphere to the middle and upper troposphere. These air parcels are then transported to Lhasa over long distances and enhanced upper and middle tropospheric ozone over Lhasa during 18-20 August 2013. Our findings demonstrate that the strong variability of ozone
\end{abstract}

within the ASM anticyclone in the free troposphere is caused by transport from very different regions of the atmosphere.

\section{Introduction}

In the troposphere, ozone acts as an important greenhouse gas, which has a positive radiative forcing $\left(0.4 \pm 0.2 \mathrm{~W} \mathrm{~m}^{-2}\right)$ through the direct or indirect greenhouse effect for the period 1750-2011. Although relatively short lived, it is therefore very important for the radiation balance of the Earth's atmosphere (Myhre et al., 2013). Enhanced tropospheric ozone has an impact on the radiative forcing of climate (Stevenson et al., 2013). Further small changes of ozone in the upper troposphere have an impact on surface climate (Riese et al., 2012). Thus, tropospheric ozone plays a major role in regional energy balance and in climate change. The variation of the tropospheric ozone mixing ratio (OMR) is associated with (1) downward transport from the stratosphere, or upward transport from the boundary layer; (2) photochemical production induced by solar radiation and other chemical reactions involving lighting-produced nitrogen oxides $\left(\mathrm{NO}_{x}\right)$ or ozone precursors from biomass burning and anthropogenic pollution. Stratosphere-troposphere exchange is affecting atmospheric tracer concentrations in a significant way via upward transport from the troposphere to the strato- 
sphere and vice versa (Holton et al., 1995; Stohl et al., 2003; Fadnavis et al., 2010, 2018; Hoor et al., 2010; Gettelman et al., 2011; Pan et al., 2016). Ozone precursors originating from biomass burning emissions may cause enhanced ozone in the free troposphere through photochemical production during tropospheric transport (Kita et al., 2002; Anderson et al., 2016). Stratospheric intrusions transport ozonerich stratospheric air downward into the troposphere (Eisele et al., 1999; Vogel et al., 2011; Weigel et al., 2012; Langford et al., 2015; Tao et al., 2018).

The Asian summer monsoon (ASM) anticyclone is the most intense circulation pattern in the Northern Hemisphere in the upper troposphere and lower stratosphere (UTLS) during boreal summer (Mason and Anderson, 1963), which is forced by deep convection over South Asia (Hoskins and Rodwell, 1995). Intense monsoon convection can transport tropospheric tracers (such as hydrogen cyanide, $\mathrm{HCN}$, produced by biomass burning; carbon monoxide, $\mathrm{CO} ; \mathrm{NO}_{x}$; or aerosols) from the lower troposphere into the UTLS of the ASM anticyclone or its edge (Chen et al., 2012; Vogel et al., 2015; Tissier and Legras, 2016; Li et al., 2017; Fan et al., 2017b; Fadnavis et al., 2018). Because of the strong dynamical confinement of the ASM anticyclone in the UTLS region in summer (Ploeger et al., 2015; Pan et al., 2016; Vogel et al., 2016, 2018), tropospheric trace gases show a local maximum near the tropopause layer within the ASM anticyclone according to satellite measurements (e.g. Park et al., 2009; Randel et al., 2010; Vernier et al., 2015; Yan and Bian, 2015; Yu et al., 2017). Tropospheric tracers within the ASM anticyclone are separated from the anticyclone and are then further transported globally. This will affect the trace gas concentration in the UTLS resulting in significant changes in radiative forcing (Garny and Randel, 2016).

The ASM anticyclone is an active region for both troposphere-to-stratosphere and stratosphere-to-troposphere transport (e.g. Garny and Randel, 2016; Fan et al., 2017a), particularly the Tibetan Plateau region (Škerlak et al., 2014). In situ balloon measurements in August 2015 in Kunming, China, combined with satellite data and model simulations show that anthropogenic emissions from Asia enter the UTLS and play a significant role in the formation of the tropopause aerosol layer within the ASM anticyclone (Yu et al., 2017). Vogel et al. (2016) show that the northeastern flank of the ASM anticyclone is a region where air masses from the ASM anticyclone are separated from the anticyclone and are subsequently transported into the extratropical lower stratosphere. When air parcels enter into the stratosphere, they have the potential to impact the regional climate in Asia (Vernier et al., 2015; Gu et al., 2016). Ozone concentrations in the planetary boundary layer over the Tibetan Plateau are most likely affected by intense deep stratospheric intrusion (Škerlak et al., 2014). Balloon measurements over the central Himalayas have shown that stratospheric intrusions enhanced ozone concentrations in the middle and upper troposphere (Ojha et al., 2014, 2017). Stratospheric intru- sions occur at the northeastern flank of the anticyclone and transport dry ozone-rich air into the troposphere over northern India. Stratospheric intrusions or tropopause folds have in addition the potential to influence surface weather including monsoon deficit rainfall (Fadnavis and Chattopadhyay, 2017). The upper tropospheric subtropical jet stream occurs from eastern Asia to the mid-Pacific with high frequency (Koch et al., 2006). Stratosphere-to-troposphere transport along the subtropical jet stream occurs over the Pacific Ocean. This is an important process for increasing ozone in the middle and upper troposphere in the region of the ASM (Trickl et al., 2011).

In particular, the Tibetan Plateau is a hotspot region for the two-way exchange between the stratosphere and troposphere (Škerlak et al., 2014). However, in situ measurements over this region of chemical compositions in the UTLS are limited (e.g. Bian et al., 2012; Li et al., 2017). Because of the sparse in situ observations over the Tibetan Plateau, there is a need for further in situ observations in this region (e.g. balloon or super-pressure balloon measurements) to obtain new insights into transport and exchange processes in this region and for climatological survey. Balloon-borne measurements provided highly accurate water vapour and ozone profiles. Measurements with such balloon payloads have been carried out in Lhasa and Kunming, China (Bian et al., 2012; Li et al., 2017); Nainital, India; and Dhulikhel, Nepal (Ojha et al., 2014, 2017; Brunamonti et al., 2018); as well as in southern India (Vernier et al., 2018). Low ozone values measured in the upper troposphere in Lhasa were presented by Li et al. (2017), and rapid vertical transport associated with typhoon convection led to this phenomenon. The ozone profiles in $\mathrm{Li}$ et al. (2017) also show anomalies of high ozone values in the middle and upper troposphere over the Tibetan Plateau; however, they provided only limited explanation of this phenomenon. Here, transport pathways of enhanced ozone values measured in August 2013 over Lhasa are analysed in more detail. It is important to investigate the ozone variation over the Tibetan Plateau, in order to quantify the uncertainty of the radiative forcing from tropospheric ozone in climate models. In this study, we combined in situ measurements with satellite data and trajectory calculations using the Chemical Lagrangian Model of the Stratosphere (CLaMS, McKenna et al., 2002; Pommrich et al., 2014) to analyse the origin of high ozone structures found in the middle and upper troposphere in Lhasa over the Tibetan Plateau in $\mathrm{Au}-$ gust 2013. This paper is organized as follows: Sect. 2 describes the balloon-borne measurements, satellite data, and the CLaMS model. In Sect. 3, we present three case studies with enhanced tropospheric ozone in August 2013. A summary is given in the final section. 


\section{Measurements and trajectory calculations}

\subsection{Balloon-borne measurements}

The SWOP (Sounding Water vapour, Ozone, and Particle) experiment was conducted in Lhasa $\left(29.66^{\circ} \mathrm{N}, 91.14^{\circ} \mathrm{E}\right.$; $3650 \mathrm{~m}$ above sea level, a.s.1.) in 2010, 2013, 2016, and 2018 and Kunming $\left(25.01^{\circ} \mathrm{N}, 102.65^{\circ} \mathrm{E}\right.$; $1889 \mathrm{~m}$ a.s.l.) in 2009 , 2011, 2012, 2014, 2015, and 2017 by the Institute of Atmospheric Physics, Chinese Academy of Sciences, during the summer monsoon period. The campaign was designed to collect the first long-term database of ozone, water vapour, and particle backscatter over the Tibetan Plateau from the surface to the lower stratosphere with the aim to investigate and quantify the character of ozone and water vapour transport within the ASM anticyclone. Vertical profiles of ozone and water vapour shown in this study are from the SWOP campaign in August 2013. A total of 24 balloons were launched during nighttime between 22:00 CST (China Standard Time, UTC + 8) and 23:00 CST in Lhasa. The payload consists of an electrochemical concentration cell (ECC) ozonesonde (Komhyr et al., 1995) to measure ozone, a cryogenic frost point hygrometer (CFH) (Vömel et al., 2007, 2016) to measure the frost (dew) point temperature for the temperature below (above) $-15^{\circ} \mathrm{C}$, and a compact optical backscatter aerosol detector (COBALD, developed at the Swiss Federal Institute of Technology, Zurich) backscatter sonde to detect aerosol or ice cloud backscatter (Brabec et al., 2012). An iMet radiosonde was used to transmit the $\mathrm{CFH}$ and COBALD data as well as to measure the ambient temperature, pressure, relative humidity (RH), and wind speed and direction. Further details about the different balloon flights during the SWOP campaign in 2013 are given by Li et al. (2017).

The relative humidity over ice $\left(\mathrm{RH}_{\mathrm{i}}\right)$ from $\mathrm{CFH}$ is defined as

$\mathrm{RH}_{\mathrm{i}}=\frac{e}{e_{\mathrm{sat}}} \times 100 \%$,

where $e$ is the water vapour pressure calculated from the frost point or dew point temperature; and $e_{\text {sat }}$ is the saturated vapour pressure with respect to liquid water or ice, which is calculated from the ambient temperature using the HylandWexler equation (Hyland and Wexler, 1983) for liquid water and the Goff-Gratch equation (Goff and Gratch, 1946) for ice water. $\mathrm{The}_{\mathrm{RH}} \mathrm{uncertainty}$ is $5 \%$ in the tropopause layer (Vömel et al., 2016).

The colour index (CI) (Rosen and Kjome, 1991) is defined as

Colour index $=\frac{\text { BSRred }-1}{\text { BSRblue }-1}$,

where BSRblue and BSRred are backscatter ratios at wavelengths of 455 and $940 \mathrm{~nm}$, respectively. CI is used to separate in-cloud $(\mathrm{CI}>7)$ from clear-sky measurements $(\mathrm{CI}<7)$ (Vernier et al., 2015; Brunamonti et al., 2018).

\subsection{Satellite data}

The Ozone Monitoring Instrument (OMI) is a nadirviewing near-ultraviolet-visible charge-coupled spectrometer aboard the National Aeronautics and Space Administration's (NASA) Earth observing system Aura satellite (Levelt et al., 2006). In this study we use the TOMS-like total column ozone (TCO) level-3 product (OMTO3e) with horizontal resolution $0.25 \times 0.25$. The TOMS version 8 algorithm is used to extract the vertical column ozone data using only two wavelengths ( 317.5 and $331.2 \mathrm{~nm}$ ). The strong ozone absorption at $317.5 \mathrm{~nm}$ is used to derive total ozone, and the weaker absorption at $331.2 \mathrm{~nm}$ is used to estimate the effective surface reflectivity. The relative uncertainty on the OMI-TOMS product is less than $5 \%$.

The Atmospheric Infrared Sounder (AIRS) on NASA's Aqua satellite is on a sun-synchronous polar orbit. The instrument employs a cross-track scanning hyper-spectral infrared spectrometer with 2378 spectral channels (Aumann et al., 2003). It is designed to provide twice-daily global data sets for different constituents and temperature. Here we use the AIRS level-2 ozone and water retrieval product version 6.0 (Olsen, 2017).

CloudSat is designed to probe the vertical structure of clouds and precipitation using a cloud profiling radar (CPR), as a component of the A-Train (Marchand et al., 2008). The CloudSat operational 2B geometric profile (2B-GEOPROF) data product (Version R04) is used with $480 \mathrm{~m}$ vertical resolution. The vertical distribution of radar reflectivity is used to mark the cloud layer. The echo mask values are greater than $20 \mathrm{dBZe}$, indicating a false detection value below $16 \%$.

\subsection{Model}

Fifty-day backward trajectories are started along the ascent profile of each balloon flight in Lhasa in August 2013. The diabatic trajectories are calculated using the CLaMS trajectory model (McKenna et al., 2002; Konopka et al., 2004; Pommrich et al., 2014). The trajectories of air parcels are calculated using the classical fourth-order Runge-Kutta method with a 1800 s time step. The CLaMS model employs a hybrid pressure-potential-temperature coordinate; detailed information about the design of the vertical coordinate was presented by Konopka et al. (2007). The trajectory has been used to focus on the transport process within or around the ASM anticyclone (Vogel et al., 2015, 2018; Ploeger et al., 2015). Dynamic fields from the European Centre for Medium-Range Weather Forecasts (ECMWF) interim reanalysis (ERA-Interim) (Dee et al., 2011) are used to drive the CLaMS model. The input dynamic fields are recorded every $6 \mathrm{~h}$ on a $1^{\circ} \times 1^{\circ}$ horizontal grid with 60 hybrid vertical levels from the surface to $0.1 \mathrm{hPa}$. The vertical velocity on the hybrid level is calculated using the diabatic heating budget including the cloud radiation, latent heat release, and 
mixing and diffusion (Ploeger et al., 2010). The trajectory model set-up is the same as in Li et al. (2017).

\section{Results}

The ozone profiles over Lhasa show a pronounced daily variation of OMRs between 340 and $420 \mathrm{~K}$ from 4 to 27 August 2013 (Fig. 1). The lapse-rate tropopause is calculated from measured temperature profiles using the lapse-rate criteria of the World Meteorological Organization (WMO) definition (WMO, 1957). The lapse-rate tropopause in Lhasa ranges from 365 to $410 \mathrm{~K}$ in August 2013. Low ozone values were measured in the upper troposphere on 11, 19, and 24 August 2013 (Fig. 1). Li et al. (2017) have combined balloon-borne measurements with the CLaMS trajectory model to highlight the low ozone structures in the upper troposphere over Lhasa. A major reason why ozone concentrations in the upper troposphere remain low is the impact from tropical cyclones, which transport marine boundary layer air with low ozone to the upper troposphere over Lhasa. However, two profiles with extremely high OMRs, up to $180 \mathrm{ppbv}$, are found in upper troposphere $(355-365 \mathrm{~K})$ on 8 August and in the troposphere from 330 to $352 \mathrm{~K}$ on 11 August 2013 (Fig. 1). Further, episodes with high OMRs occurred from the middle troposphere to the lower stratosphere during 18-20 August 2013. Whereas Li et al. (2017) discuss low ozone values in August 2013, here we will focus on extremely high ozone values.

\subsection{High ozone and long-range transport on 8 August 2013}

Figure 2a shows the vertical profiles of temperature, OMR, monthly mean ozone, $\mathrm{RH}$, and OMR relative change. The positive OMR anomalies with a value up to $180 \mathrm{ppbv}$ occur between 355 and $365 \mathrm{~K}$, which is below the lapse-rate tropopause (378 K) on 8 August 2013 (Fig. 2a left). The OMR relative change shown in Fig. 2a (right) shows the percentage deviation of the ozone profile observed on 8 August from the monthly mean ozone profile obtained by averaging 24 profiles over Lhasa in August 2013. The data show ozone anomalies up to $90 \%$ on 8 August compared to monthly mean ozone. The high ozone value is marked by dark shading for the OMR relative changes above $30 \%$; in the following, we solely focus on these air masses. Unfortunately, $\mathrm{RH}_{\mathrm{i}}$ from $\mathrm{CFH}$ is not available above $335 \mathrm{~K}$. Instead, the relative humidity (RH) from iMet was used, with useful data just below $350 \mathrm{~K}$ (above $-40^{\circ} \mathrm{C}$ ). Below $-40^{\circ} \mathrm{C}$, RH will not be used, because of the detection limit of the radiosonde humidity sensor.

The potential vorticity (PV) along the 30-day backward trajectories of air parcels with high ozone concentrations between 355 and $362.3 \mathrm{~K}$ was shown in Fig. $2 \mathrm{~b}$ as a function of time and potential temperature. According to their different

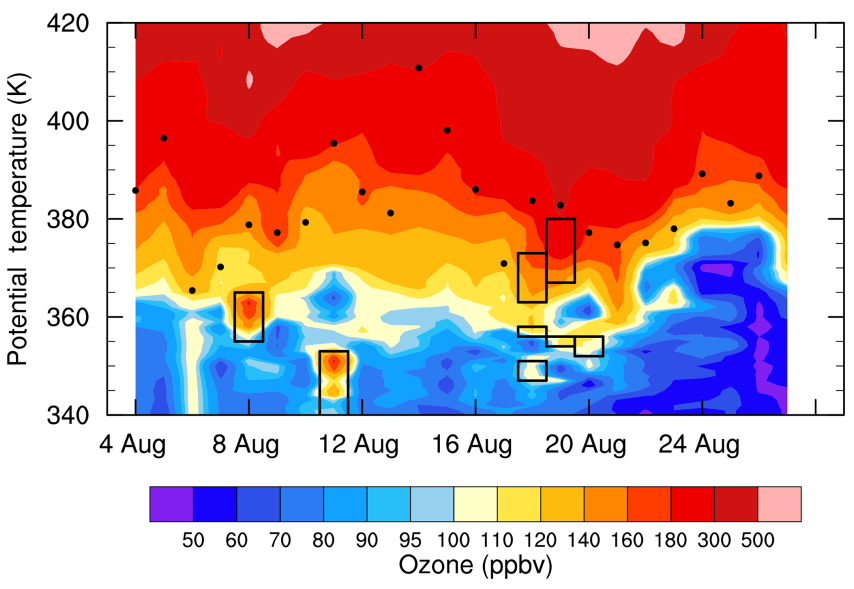

Figure 1. Daily variations of ozone mixing ratios (OMRs) between 340 and $420 \mathrm{~K}$ during 4-27 August 2013 from balloon measurements launched in Lhasa. The black dots represent the lapse-rate tropopause. High tropospheric ozone is shown by the black rectangles.

pathways, backward trajectories of air parcels could be divided into two clusters. Both of them experienced strong uplift processes with potential temperature increasing from 330 to $360 \mathrm{~K}$ on 20 and 29 July. The tracks of 20-day backward trajectories of air parcels around 355-362.3 K isentropes initialized on 8 August 2013 are shown colour-coded by date in Fig. 2c. Air parcels started their ascent near the Himalayas and were uplifted to the $360 \mathrm{~K}$ isentrope from 19 to 21 July and then moved horizontally to East Asia following the ASM anticyclone. Finally, the air parcels moved westerly around the anticyclone circulation before they arrived in Lhasa on 8 August 2013. The transport time for the air parcels from the lower troposphere of the Himalayas to the upper troposphere over Lhasa is less than 20 days for the whole pathway.

Figure $2 \mathrm{~d}$ gives the boundary layer geolocation of air parcels (the same as in Fig. 2b and c), where they experience strong uplift through convection. The uplift rate of the air parcel is defined as $\left(\theta_{t+\delta t}-\theta_{t}\right) / \delta t$. When the uplift rate is greater than $9 \mathrm{Kday}^{-1}$ (an empirical value), the strong uplift process of air parcels will be recognized. The point that air parcels start ascent is marked as the geolocation. We find that most of the air parcels were from the Himalayas, where strong uplift occurred frequently. South Asia, the area adjacent to the Himalayas is usually a strong source region of air pollution, which is caused by natural (e.g. biomass burning) and anthropogenic processes (Cong et al., 2015). In addition, ozone is photochemically enhanced by reactions involving ozone precursors from biomass burning. After reaching the upper troposphere, the polluted air masses that were transported over long distances made the best possible contribution to high tropospheric ozone over Lhasa at nighttime on 8 August 2013. 


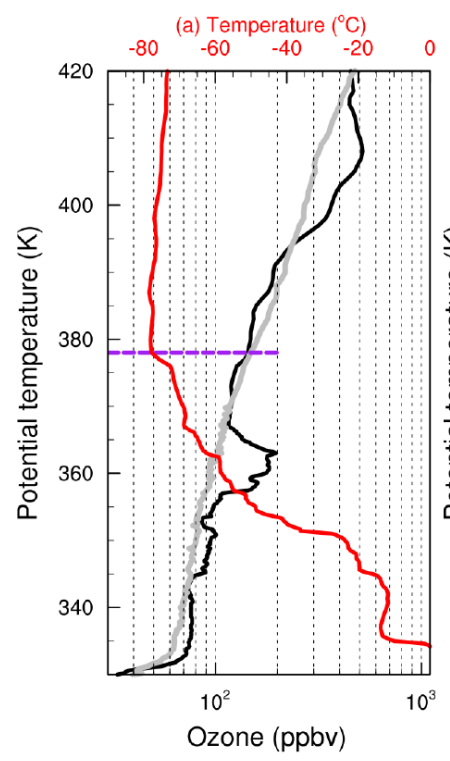

(c) 20-day backward trajectories

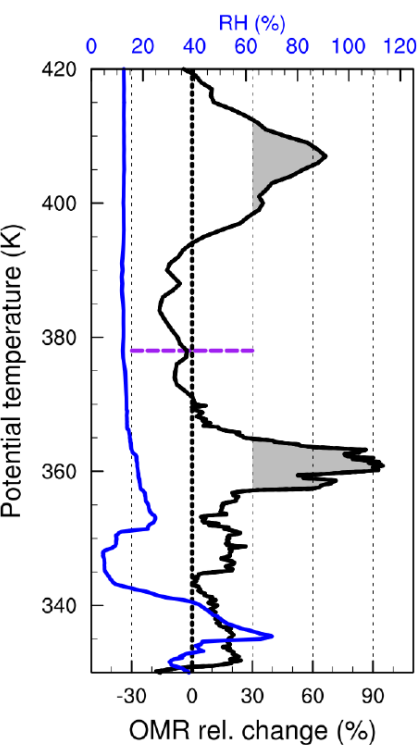

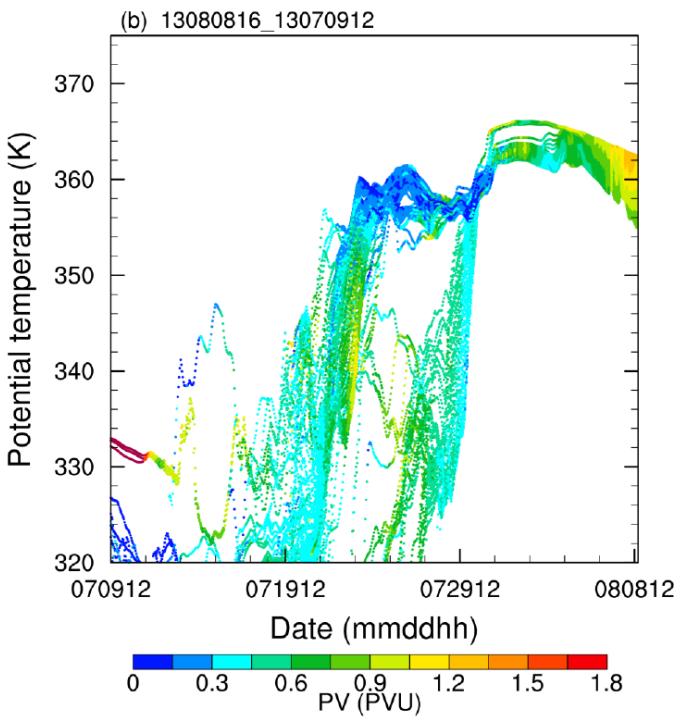

(d)

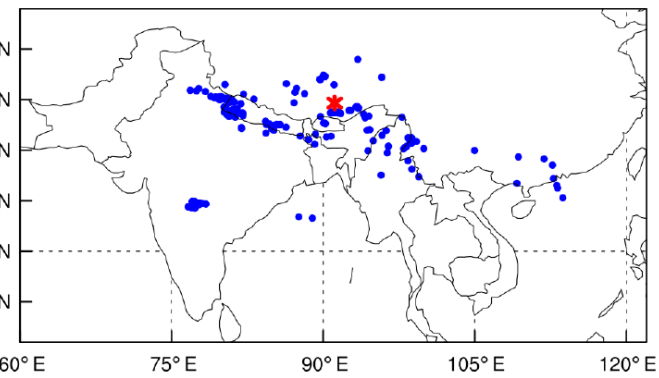

Figure 2. (a) Vertical profiles of ozone (black), monthly mean ozone (grey), and temperature (degree in red), OMR relative change (black), and relative humidity (blue) in Lhasa on 8 August 2013, 14:00 UTC. The horizontal line marks the lapse-rate tropopause. (b) Potential vorticity (1 PVU $=10^{6} \mathrm{~K} \mathrm{~m}^{2} \mathrm{~kg}^{-1} \mathrm{~s}^{-1}$; PVU stands for the unit of potential vorticity) along the 30-day backward trajectories of air parcels within the high ozone layer $(355-362.3 \mathrm{~K})$ as a function of time and potential temperature. (c) The 20-day backward trajectories of air parcels between 355 and $362.3 \mathrm{~K}$ at the Lhasa site on 8 August 2013 are shown colour-coded by date. (d) Geolocation of air parcels experienced strong uplift in the positive ozone mixing ratio anomalies. The red asterisk marks the location of Lhasa.

\subsection{High ozone and high water vapour on 11 August 2013}

The vertical variability of OMR, monthly mean ozone, temperature, the OMR relative change, $\mathrm{RH}_{\mathrm{i}}$, and $\mathrm{CI}$ on $11 \mathrm{Au}$ gust 2013 are shown in Fig. 3a. Positive ozone anomalies (Fig. 3a left) and the OMR positive variance with a value up to $125 \%$ (Fig. 3a right) appeared from the surface to the midtroposphere (330-353 K) on 11 August 2013. The $\mathrm{RH}_{\mathrm{i}}$ shows a high value $(>70 \%$ ) between 336 and $350 \mathrm{~K}$. CI from the COBALD shows that a thick cirrus cloud layer occurred below $349 \mathrm{~K}$. The finding of high ozone concentration accompanied by high water vapour values within a thick cloud layer is unusual over the Tibetan Plateau in our measurement.

PV values along the 50-day backward trajectories of air parcels with high ozone concentrations between 340 and $354 \mathrm{~K}$ are shown in Fig. 3b. The results show that the PV val- ues are less than 1.5 PVU in the troposphere. Air parcels were uplifted to the upper troposphere through convection, then they are transported over a long distance, and descended before they arrived in Lhasa. Three-dimensional backward trajectories of air parcels within the high ozone structure were shown in Fig. 3c. Particles were first uplifted to the upper troposphere and these were moved around the ASM anticyclone within 4-5 weeks. Air pollution from the South Asia boundary layer has the potential to impact the ozone structure over Lhasa via transportation around the ASM anticyclone within 4-5 weeks.

Figure 3d gives the boundary layer geolocation, where parcels experienced strong uplift. Most of the air parcels are transported from South and Southeast Asia, a region with high air pollution, to Lhasa. Few of the air parcels originated from South China and the Tibetan Plateau. Obviously, the $\mathrm{RH}_{\mathrm{i}}$ is controlled by local microphysical cloud processes 

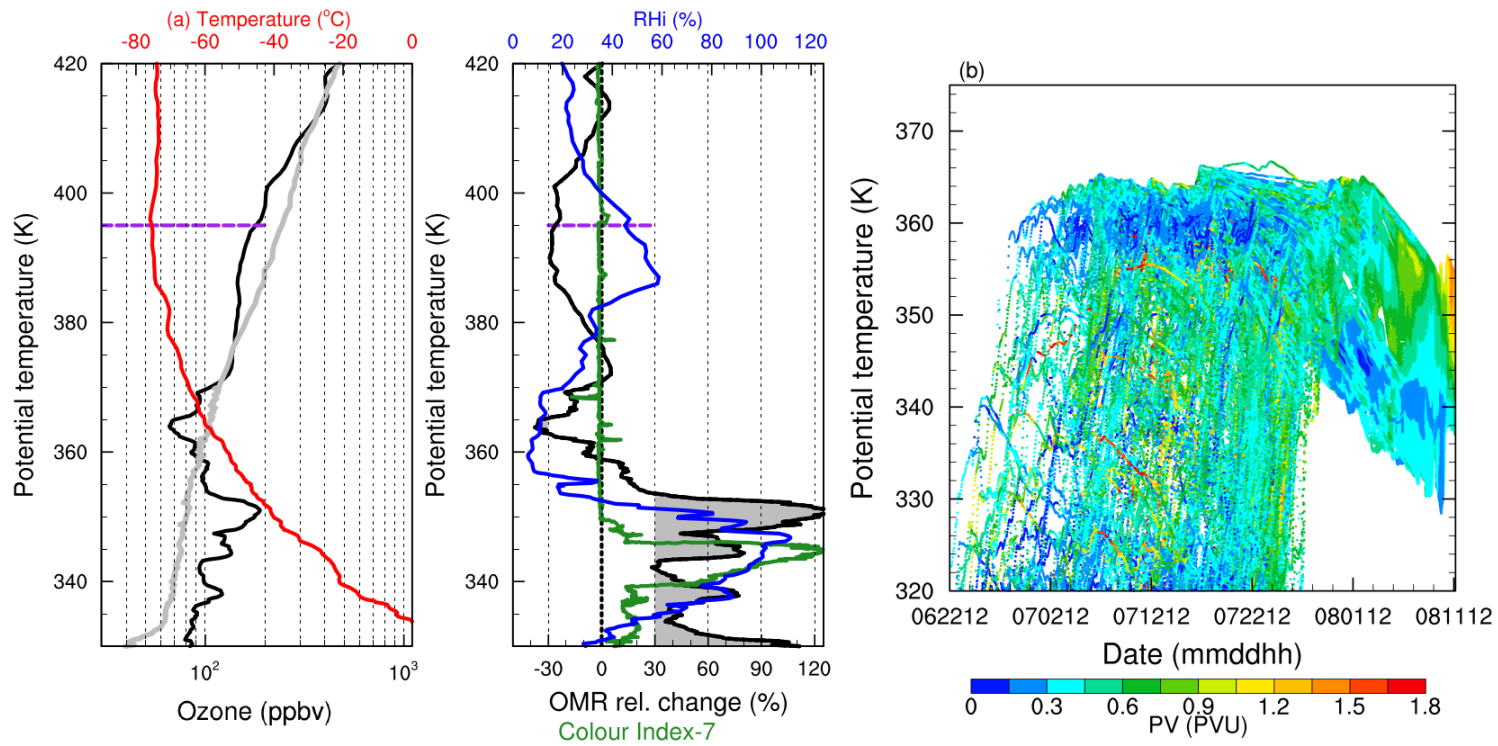

(c) 50-day backward trajectories: 2013081115 UTC
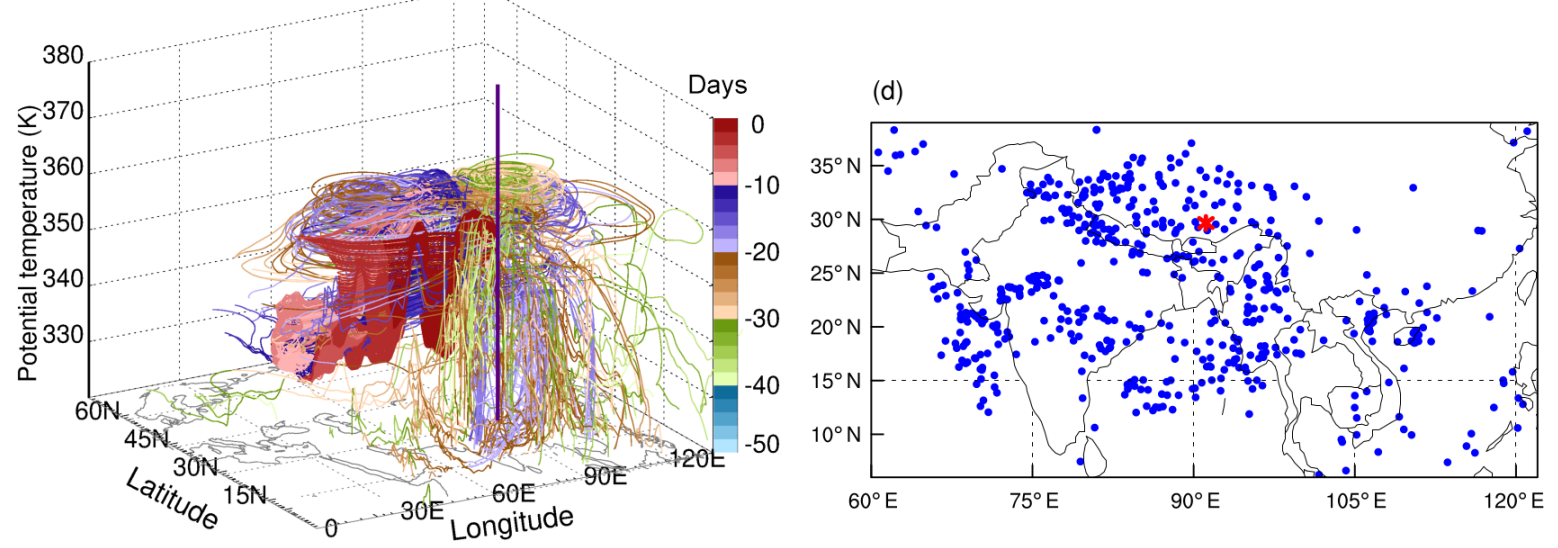

Figure 3. The same as Fig. 2 except for panel (c) but on 11 August 2013. (a) Colour index (CI) minus 7 (CI $-7>0$ marks the cirrus cloud layer, green line). (c) Three-dimensional backward trajectories colour-coded by days.

according to the $\mathrm{CI}(\mathrm{CI}>7$, in-cloud measurements). The horizontal scale of the cloud is less than $1 \times 1^{\circ}$ according to the MODIS satellite (figure not shown). Air pollutants from South Asia or Lhasa may contribute to the positive ozone anomalies over Lhasa through photochemical production; however, due to the detection limit for chemical constituents that produces ozone over the Tibetan Plateau during this period, it is not clear what the reasons for high ozone within cirrus clouds are.

\subsection{Stratospheric intrusion on 18-20 August 2013}

Figure 4a shows the total column ozone from the OMI satellite along with the geopotential height, $\mathrm{PV}$ at $150 \mathrm{hPa}$, and the sea-level pressure of Typhoon Utor on 16 August 2013. The PV clearly displays a filament structure extending from northeastern Asia to the southeastern edge of the ASM anticyclone on 16 August 2013. TCO displays the same structure as the PV over northeastern Asia, where stratospheric intrusions occur frequently ( $\mathrm{Li}$ and Bian, 2015; Song et al., 2016). The enhanced TCO values are first of all indicative of an extratropical intrusion. Since the stratosphere contributes most to the column, it is also indicative of an intrusion of stratospheric air. This is further supported by the good correlation of TCO with PV values at $150 \mathrm{hPa}$. The PV on the $370 \mathrm{~K}$ isentropic surface shows the same structure as the PV at the $150 \mathrm{hPa}$ pressure level (Fig. 4b). The stratospheric intrusion with high OMRs is also reflected in low water vapour values observed by AIRS at $83.666 \mathrm{hPa}$ during its ascending track on 16 August 2013 (Fig. 4c and d). The filament structure is subsequently separated from the stratosphere. The remnant of the stratospheric intrusion (Rossby wave breaking filament) moves westward along the easterly wind flow at the southern flank of the ASM anticyclone. During the next few days, this broken filament structure moves westward about $3000 \mathrm{~km}$. It arrives in Lhasa and is captured by the ozoneson- 

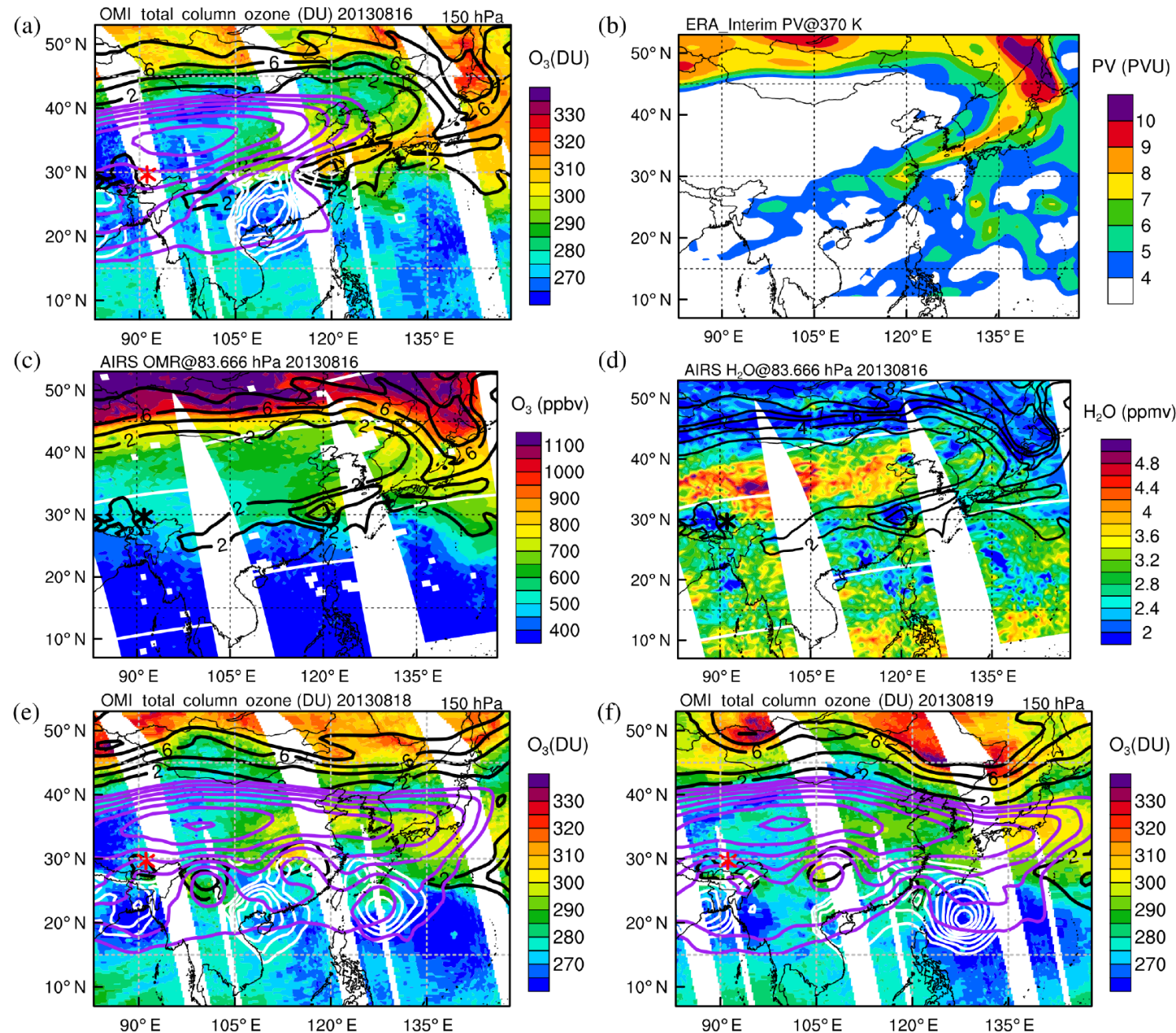

Figure 4. Total column ozone (DU) as measured by OMI with the geopotential height (purple line) and PV (black line, in PVU) at $150 \mathrm{hPa}$, and the sea-level pressure (white line) of tropical cyclone on (a) 16, (e) 18, and (f) 19 August 2013 using ERA-Interim data. (b) The PV (shade, PVU) on the $370 \mathrm{~K}$ surface on 16 August 2013. (c) Ozone and (d) water vapour mixing ratios for $83.666 \mathrm{hPa}$ from AIRS on 16 August 2013 with PV at $150 \mathrm{hPa}$ from ERA-Interim. The asterisk marks the location of Lhasa.

des launched on 18 and 19 August 2013 (Fig. 4e-f) and on 20 August 2013 (figure not shown), contributing to the positive ozone value measured in the UTLS region over Lhasa.

Figure 5a shows the vertical variability of ozone, monthly mean ozone, temperature, $\mathrm{RH}_{\mathrm{i}}, \mathrm{CI}$, and the OMR relative change for 18 August 2013. The positive OMR relative change appears in the troposphere around 350 and 363$373 \mathrm{~K}$, as well as in the lower stratosphere (Fig. 5a right). Two characteristic minima of OMR relative change occur between $352-357$ and $375-390 \mathrm{~K}$ on 18 August. $\mathrm{RH}_{\mathrm{i}}$ is negatively correlated with OMR anomalies on these isentropic surfaces. $\mathrm{RH}_{\mathrm{i}}$ near the tropopause $(384 \mathrm{~K})$ is greater than $100 \%$. Indeed, an ice cloud layer was observed near the tropopause layer according to the $\mathrm{CI}(\mathrm{CI}>7)$ from COBALD backscatter measurements. Supersaturation is observed within the ice cloud.
In order to investigate in detail the variance of ozone profiles measured on 18 August 2013, the PV along the 50-day backward trajectories from the CLaMS model is displayed in Fig. 5b. Parcels in the upper troposphere (363-373 K) originate from the dry stratospheric intrusion layer. There is evidence for mixing processes that occurred between air parcels with high PV from the stratosphere and a low PV value from the troposphere, while air parcels in the middle troposphere (around $350 \mathrm{~K}$ ) with high ozone and low water vapour originate from the thin intrusion layer. Air parcels around $350 \mathrm{~K}$ experienced a weak uplift during 13-14 August 2013. Figure $5 \mathrm{c}$ shows the tracks of backward trajectories of air parcels on $350-352$ and $363-373 \mathrm{~K}$ on 18 August, respectively. Only 20-day backward trajectories of air parcels are shown colourcoded by potential temperature here. This is long enough to show the intrusion pathway. The thin intrusion layer with low potential temperature $(338 \mathrm{~K})$ moved toward the north 

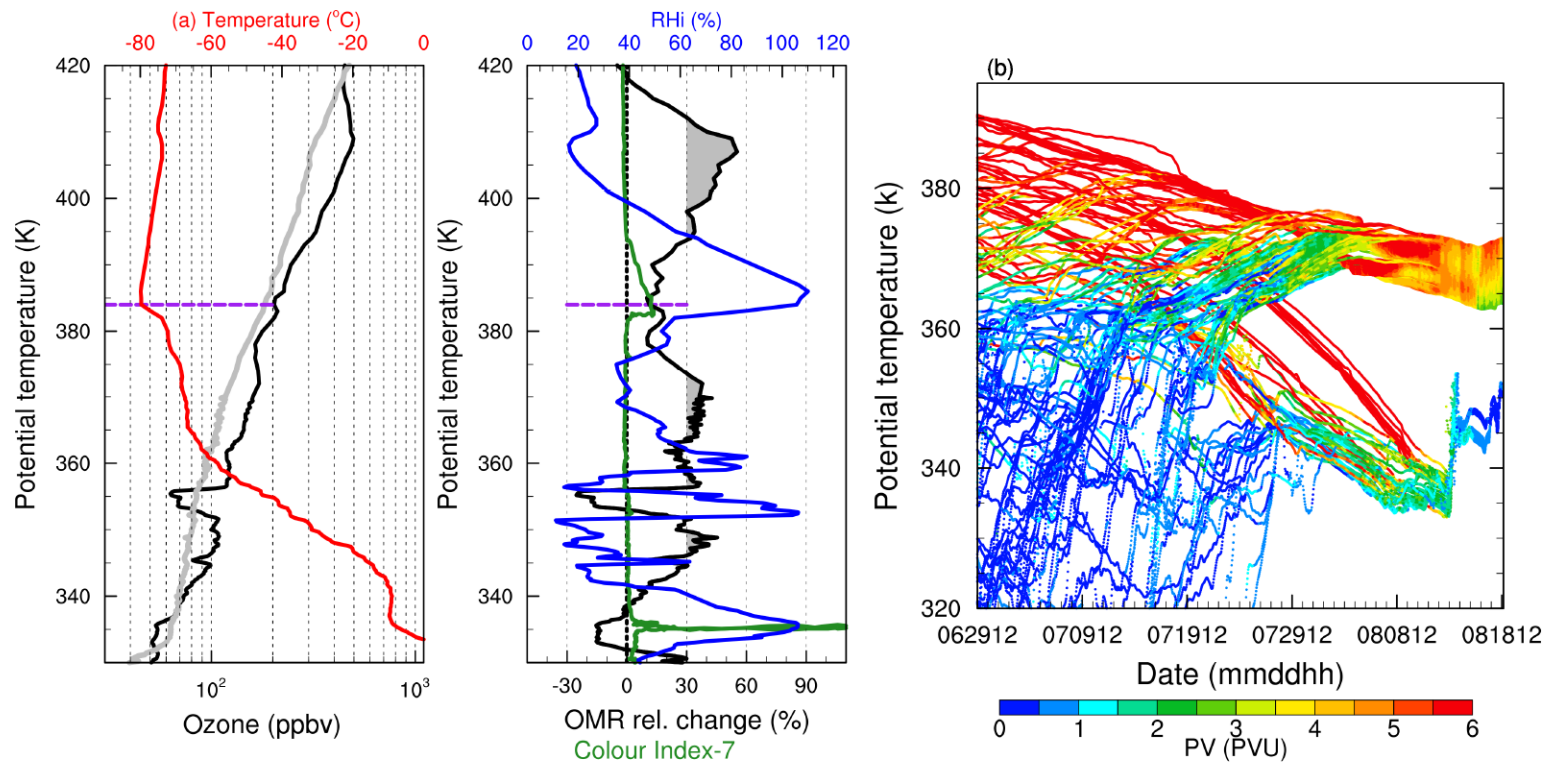

(c) 20-day backward trajectories

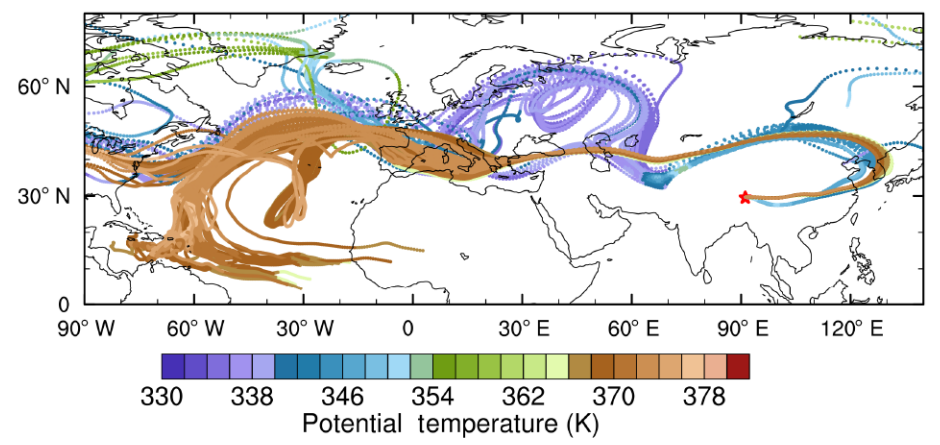

Figure 5. Panels (a, b) are the same as Fig. 3a-b but on 18 August 2013. (c) The 20-day backward trajectories of air parcels within the high ozone layer are shown colour-coded by potential temperature.

around the anticyclone and then showed a strong equatorward movement from 60 to $30^{\circ} \mathrm{N}$ around $60^{\circ} \mathrm{E}$. The intrusion layer in the upper troposphere experienced a mixing process according to the PV along the trajectories. Air parcels with high PV values from the Northern Hemisphere were mixed with air parcels with low PV from the region at approximately $35^{\circ} \mathrm{N}, 60^{\circ} \mathrm{W}$ over the North Atlantic. Although ozone-rich air mixed with ozone-poor air from the equatorial region, the positive ozone anomalies still appeared in the upper troposphere on 18 August 2013. As Riese et al. (2012) show, ozone concentrations are sensitive to mixing strength in the lower stratosphere.

Positive ozone anomalies were also captured on 19 and 20 August 2013. The variability of ozone vertical structure is significant in the middle troposphere on 19 August. Ozone and water vapour show strong anti-correlation below $355 \mathrm{~K}$. The OMR relative change shows a large increase in the tropopause region (368-408 K), up to $90 \%$ (Fig. 6a). The 50-day backward trajectories of air parcels in Fig. 6b indicate a diabatic decent transport process, especially the air cluster in the middle troposphere (between 347 and $355 \mathrm{~K}$ ). The PV along the trajectories of air parcels between 368 and $380 \mathrm{~K}$ displays high PV with values greater than $6 \mathrm{PVU}$. Figure $6 \mathrm{c}$ shows the tracks of backward trajectories of air parcels within high ozone in the middle and upper troposphere on 19 August. The stratospheric intrusion in the middle troposphere has the same transport pathway as on $18 \mathrm{Au}-$ gust and also experienced an uplift process around $14 \mathrm{Au}-$ gust. Air parcels near the tropopause layer (368-380 K) originated from the Northern Hemisphere with high ozone and high PV. The equatorial regions contribute little to air parcels on 19 August compared to the case on 18 August. That is why the OMR relative change near the tropopause layer on 19 August is higher than the OMR relative change on $18 \mathrm{Au}-$ gust.

The ozone vertical structure and $\mathrm{RH}_{\mathrm{i}}$ also show an anticorrelation in the middle troposphere on 20 August. In the troposphere, the OMR relative change near $355 \mathrm{~K}$ is higher than $30 \%$. The OMR relative change on 20 August shows minor increases in the tropopause region (Fig. 7a) and is 

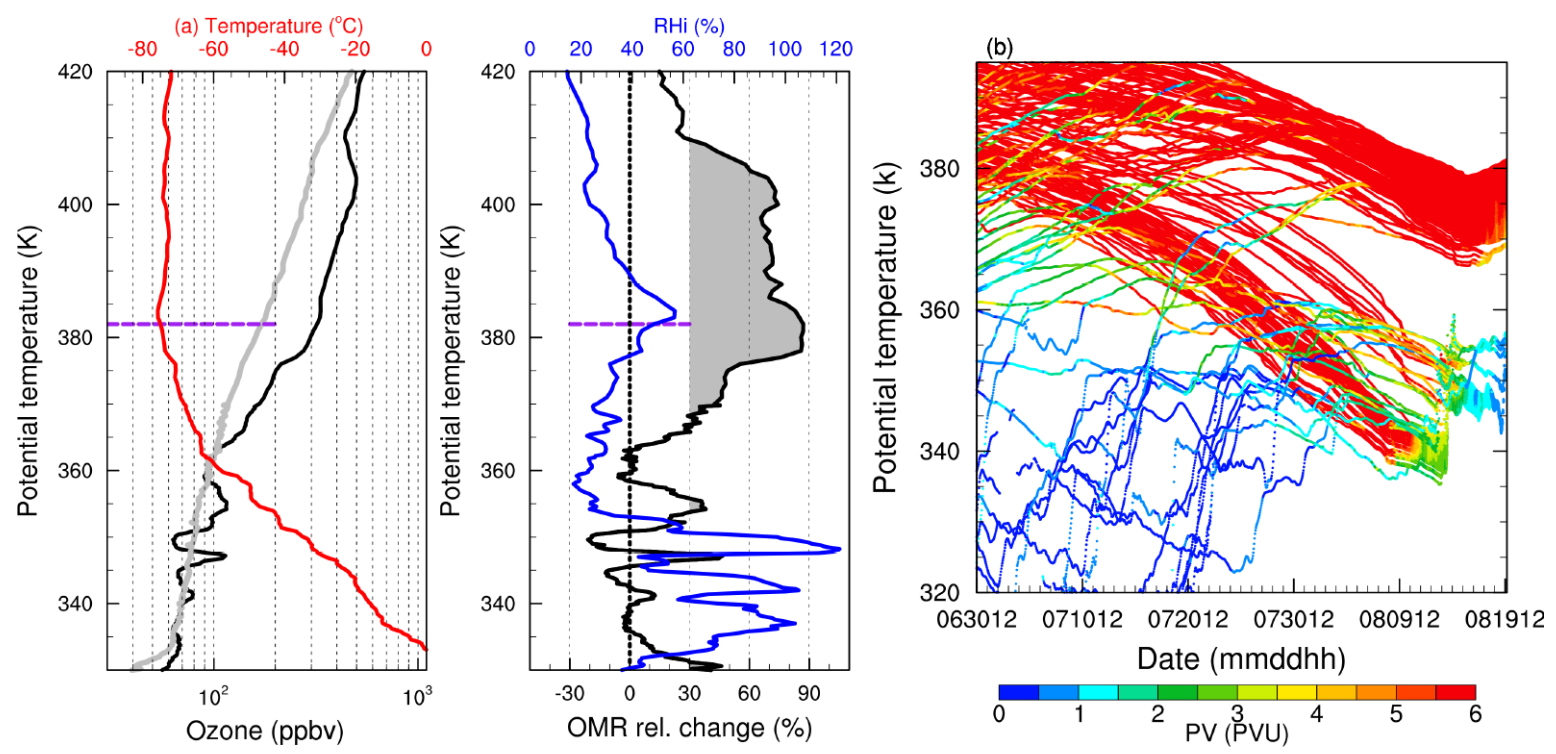

(c) 20-day backward trajectories

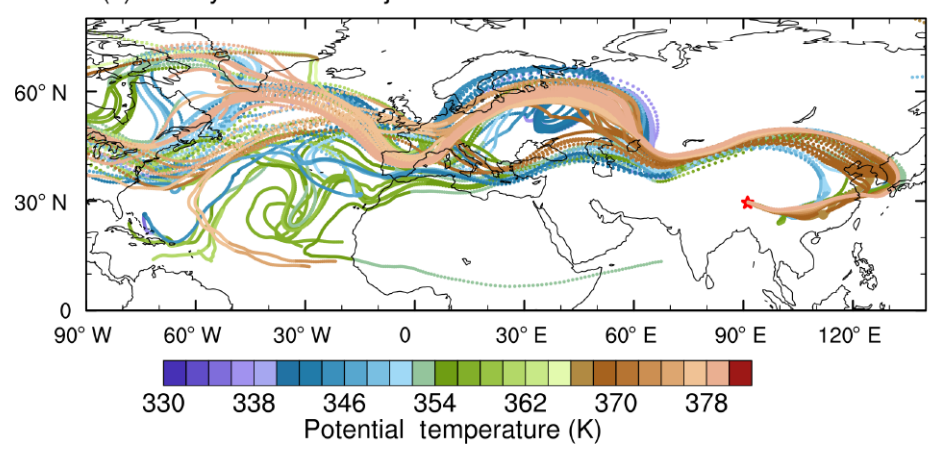

Figure 6. The same as Fig. 5, but on 19 August 2013.

also weaker than on 19 August. The height of lapse-rate tropopause on 20 August is lower than on 18 and 19 August. Fig. $7 \mathrm{~b}$ shows the PV along the backward trajectories of air parcels in the middle troposphere ( $355 \mathrm{~K})$ on 20 August. The intrusion in the middle troposphere has the same transport pathway as the one on 18 August and also experienced an uplift process around 14 August (Fig. 7c).

In order to explore the intrusion structure in the middle troposphere, the OMR from the AIRS satellite at $346 \mathrm{hPa}$ is shown on 13 August 2013, 08:30 UTC, with PV at $350 \mathrm{hPa}$ from ERA-Interim on 13 August 2013, 06:00 UTC (Figure 8a). Both ozone and PV show that a filament structure extends from the south of Afghanistan via Tian Shan to Russia in the northern extratropics. Meanwhile, the latitudepressure cross section of the AIRS ozone along $70^{\circ} \mathrm{E}$ displays a tropopause fold. The intense stratospheric intrusion transported air with high ozone from the tropopause layer downward to the surface of the mountain at $40^{\circ} \mathrm{N}$ (Fig. 8b). The structure of the tropopause fold from PV and ozone is a little shifted, because of the time difference between AIRS ascending time (around 08:30 UTC) and ERA-Interim reanalysis data (06:00 UTC).
Figure $9 \mathrm{a}-\mathrm{c}$ show the cross section of the square of the Brunt-Väisälä frequency $\left(N^{2}\right)$ along the average longitude of the bottom air cluster in Fig. 5b on 10 August, 06:00 UTC; on 12 August, 18:00 UTC; and on 13 August, 12:00 UTC, with potential temperature, PV, zonal wind, and the lapserate tropopause calculated from the ERA-Interim reanalysis. The radar reflectivities (dBZe) measured by the CloudSat's CPR are shown in Fig. 9d. Air parcels are located in the extratropical lowermost stratosphere (350-380 K) above the lapse-rate tropopause (near $330 \mathrm{~K}$ ) on 10 August 2013, 06:00 UTC (Fig. 9a). These parcels moved equatorward and arrived at the poleward edge of the westerly wind jet 2 days later, where a tropopause fold occurred (Fig. 9b). Parcels continue to move along the isentropic surfaces and cross the tropopause region from the polar lowermost stratosphere to the upper troposphere in the mid-latitude on 13 August 2013, 12:00 UTC (Fig. 9c). Overall, it takes 2-3 days for air parcels to cross the tropopause. Both the pathway and timescale of transport are consistent with the analysis of other deep stratospheric intrusions that occurred over North America (Langford et al., 1996; Vogel et al., 2011; Kuang et al., 2012; Lin et al., 2015) or Europe (Stohl and Trickl, 1999; Trickl et al., 

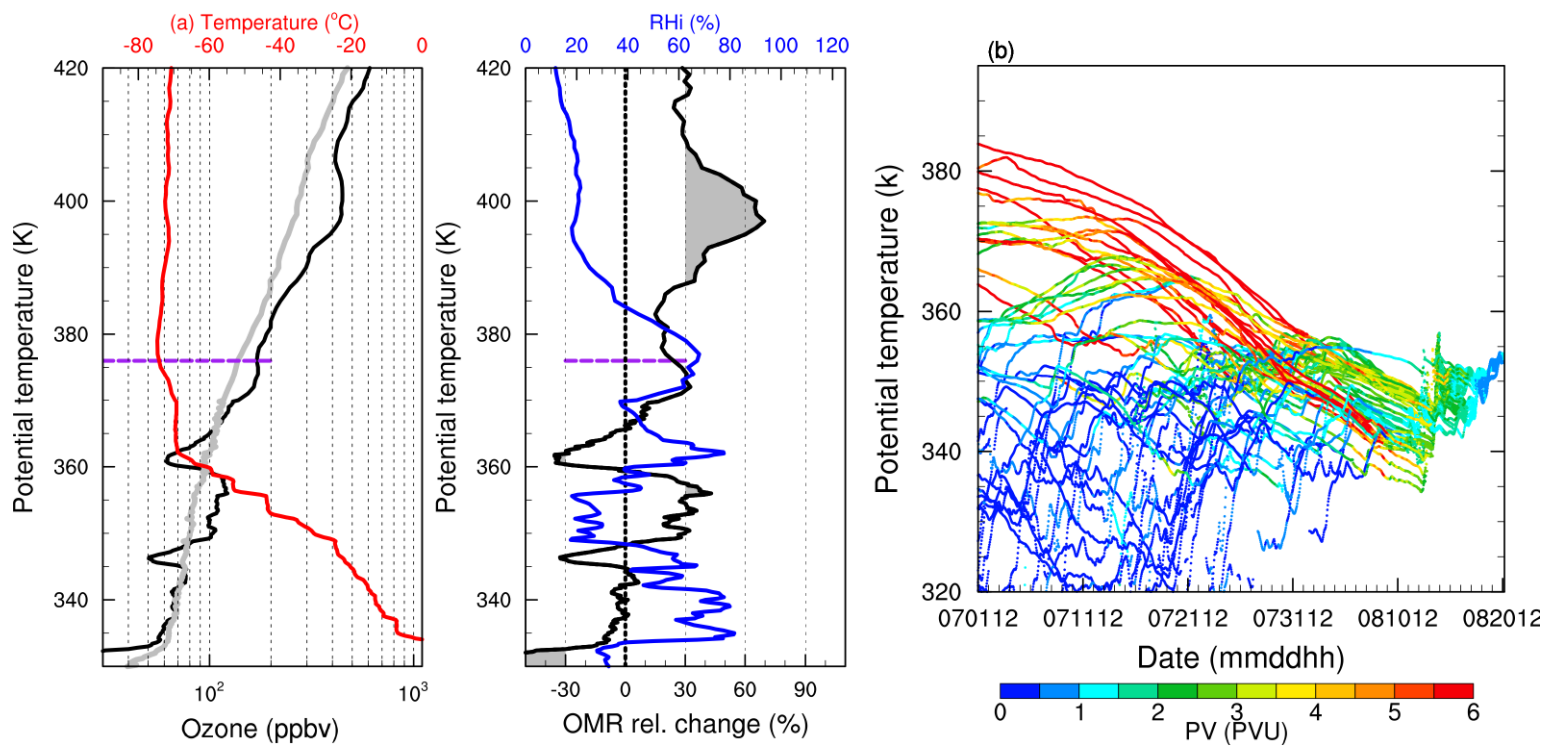

(c) 20-day backward trajectories

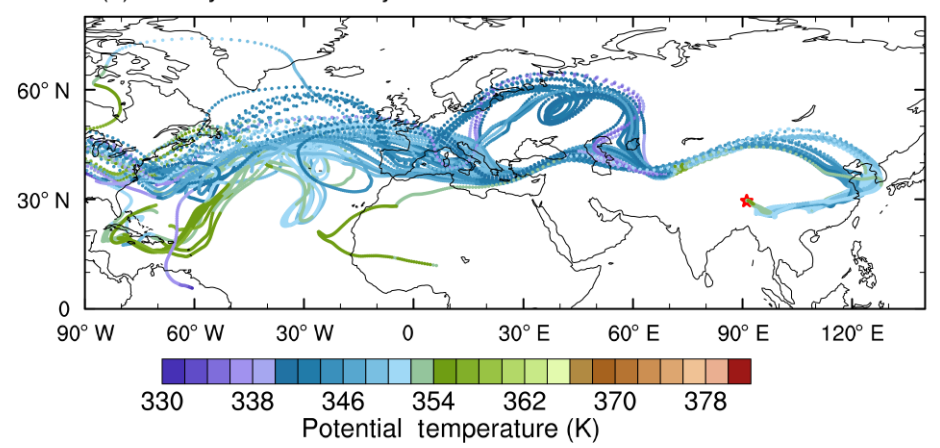

Figure 7. The same as Fig. 5, but on 20 August 2013.
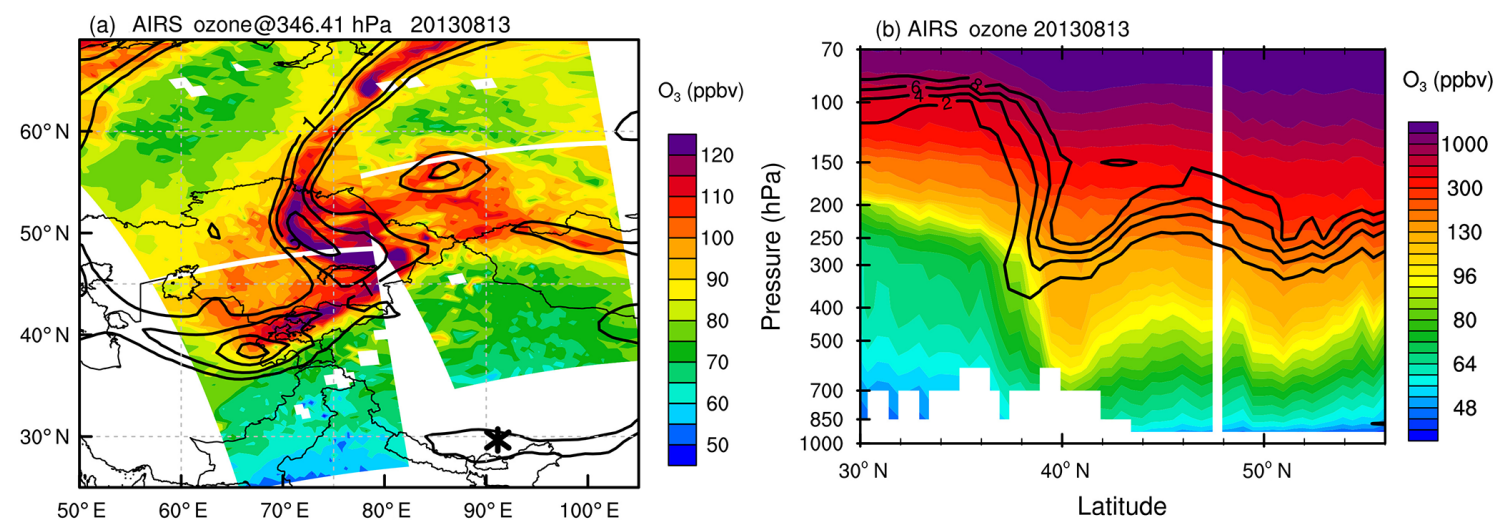

Figure 8. (a) Ozone volume mixing ratio for $346.41 \mathrm{hPa}$ on 13 August at about 06:00 UTC from the AIRS satellite. (b) Latitude-pressure cross section of ozone along $70^{\circ} \mathrm{E}$ with PV $(2,4,6$, and 8 PVU, black line).

2010, 2014) associated with the polar jet stream. It is interesting that, in our case, air parcels are affected by strong convection in the troposphere, after they are transported from the stratosphere downward into the upper troposphere. The strong convection lifted air parcels to high altitude, which can be seen from the CloudSat radar reflectivity (Fig. 9d). This uplift process can be seen clearly on 14 August 2013 in Fig. 5b. The extratropical tropopause is located between the upper troposphere and lower stratosphere and intersects the isentropic surface, which acts as a dynamic barrier for 
(a) 2013081006 UTC

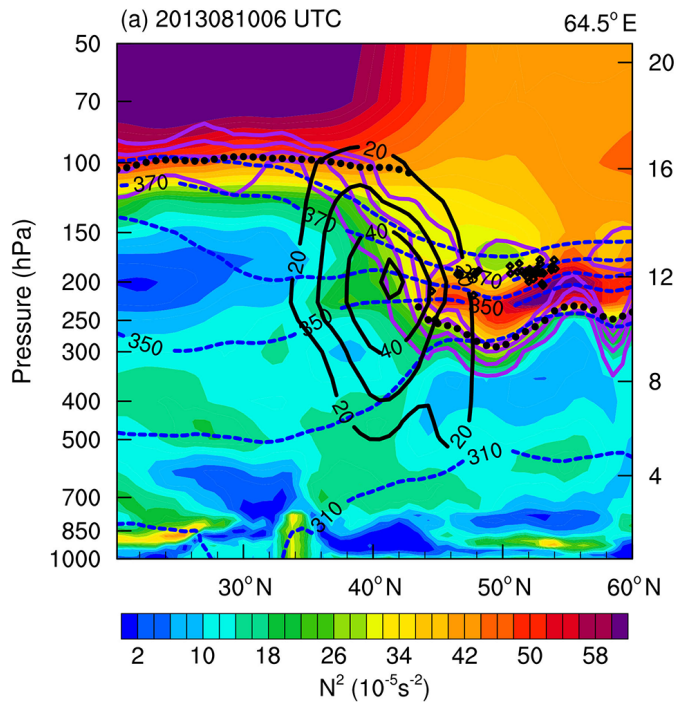

(c) 2013081312 UTC

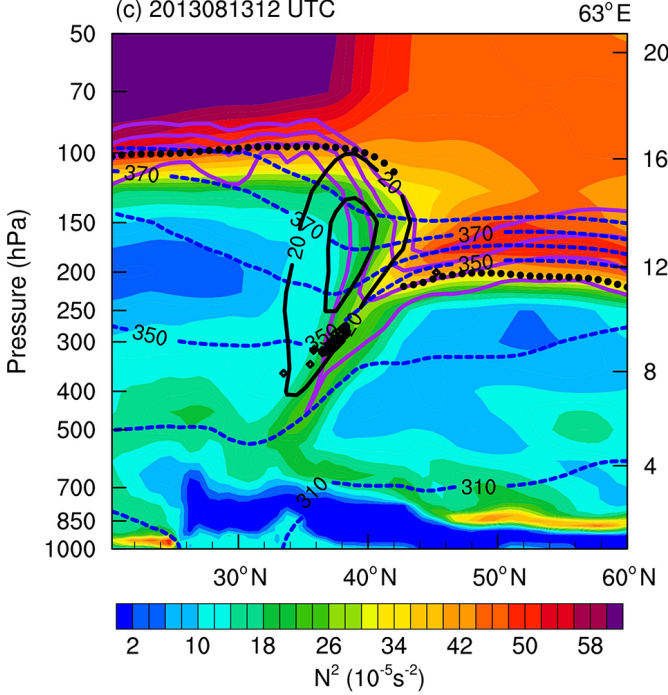

(b) 2013081218 UTC

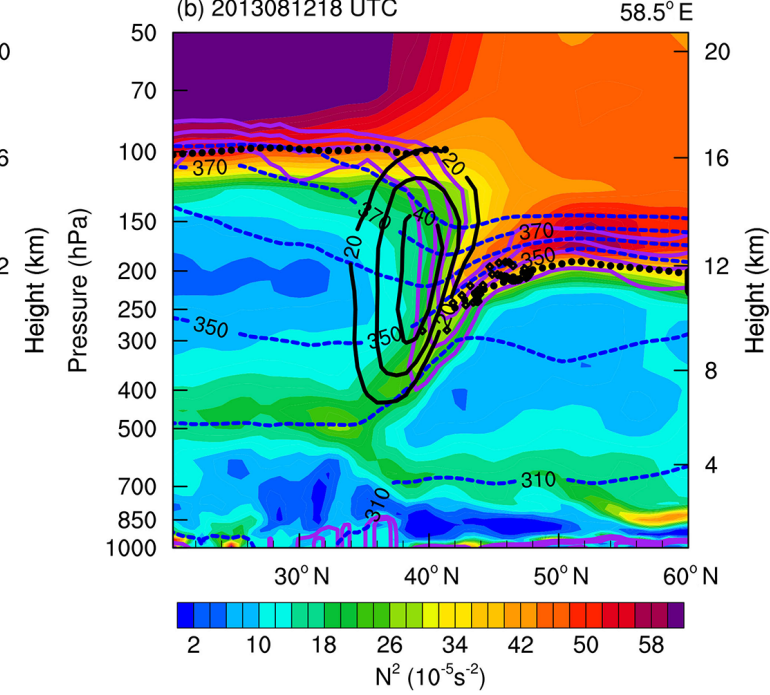

(d) 2013081400 UTC

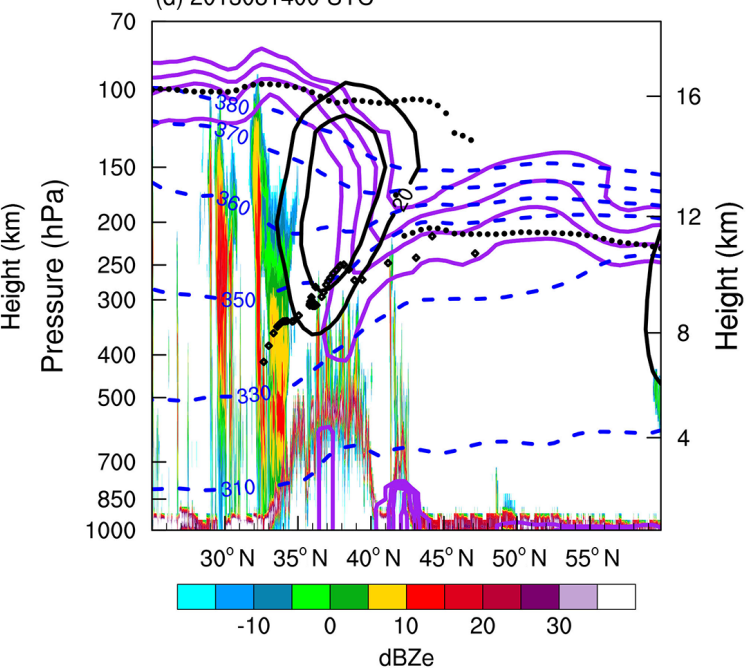

Figure 9. Latitude-pressure cross section of the square of the Brunt-Väisälä frequency $\left(N^{2}\right)$ along the average longitude of the bottom air parcels in Fig. 5b on (a) 10 August, 06:00 UTC; (b) 12 August, 18:00 UTC; and (c) 13 August, 12:00 UTC, with potential temperature (blue dashed lines, K), PV (purple lines, PVU), tropopause (black dots, hPa), zonal wind (black lines) from ERA-Interim, and air parcels (diamonds) from the CLaMS trajectory model. (d) The same as panel (a) except for radar reflectivity (dBZe) but on 14 August, 00:00 UTC, from CloudSat.

tracer transport (Gettelman et al., 2011). Ozone in the extratropics exhibits large gradients in the UTLS. There is a net downward transport of ozone from the stratosphere to the troposphere along the isentrope at the poleward edge of the jets (Yang et al., 2016). The tropopause fold transports air parcels quasi-isentropically from the lowermost stratosphere with high ozone mixing ratio to the troposphere within the ASM anticyclone, contributing to high tropospheric ozone over the Tibetan Plateau on 18, 19, and 20 August 2013.

\section{Discussion and conclusions}

Balloon-borne measurements of ozone and water vapour mixing ratios over Lhasa in August 2013 are investigated using the OMI and AIRS satellite data and backward trajectory calculations using the CLaMS model. We focus on enhanced OMRs observed in the middle and upper troposphere over Lhasa on 8, 11, and 18-20 August 2013.

For 8 and 11 August, trajectory calculations show that the enhanced ozone concentrations may result from air pollution originating from South Asia, which reached the measurement location through convective uplift and quasi-horizontal long-range transport within 20 days. Here we mainly focused on 20-day backward trajectories. To study transport 
processes in the region of the Asian monsoon, a trajectory length between a few days to a few months is found in the literature (e.g. Chen et al., 2012; Bergman et al., 2013; Vogel et al., 2014; Vernier et al., 2015; Garny and Randel, 2016; Li et al., 2017). To study the convective events, a trajectory length of a few days to 20 days is sufficient. Garny and Randel (2016), using isentropic trajectory calculations, also show that air parcels originating at $360 \mathrm{~K}$ within the anticyclone were confined within the ASM anticyclone for 10-20 days. Li et al. (2017), using the Lhasa's balloon data in 2013 and the CLaMS trajectory model, have shown that air parcels with low ozone from the marine boundary layer over the western Pacific are the dominant source of low ozone in the tropopause layer in Lhasa resulting from very strong uplift (1-4 days) by typhoons and subsequent horizontal long-range transport (4-10 days) within the ASM anticyclone. Thus, 20-day backward trajectories from the CLaMS model for the middle and upper troposphere within the ASM anticyclone are generally appropriate. However, to analyse aged air masses transported in the region of the ASM anticyclone or originating in the stratosphere, trajectories longer than 20 days are necessary (e.g. Chen et al., 2012; Bergman et al., 2013; Vogel et al., 2014; Garny and Randel, 2016). The longer the trajectories run, the larger are the uncertainties due to trajectory dispersion and the lack of mixing processes in the simulations (McKenna et al., 2002). For trajectories from the stratosphere we calculated a set of trajectories close to the location of the measurement (not shown here) and found that all these trajectories show a very similar transport pattern over the last 20 days.

During the ASM period, deep convective clouds occurred over the South Asian subcontinent, the southern Himalayan region, and the Tibetan Plateau that caused lightning activity (Qie et al., 2014). $\mathrm{NO}_{x}$ produced by lighting has the potential to impact upper tropospheric ozone via photochemical reactions (Kita et al., 2002; Schumann and Huntrieser, 2007; Fadnavis et al., 2015; Gottschaldt et al., 2018). Uplifted ozone precursors and $\mathrm{NO}_{x}$ produced by lighting contribute to photochemical ozone production in the upper troposphere in the ASM anticyclone. An ozone increase by $30 \%$ is found over the monsoon convection region due to $\mathrm{NO}_{x}$ enhanced by lightning according to sensitivity simulations with and without lightning (Fadnavis et al., 2015). In our case studies, ozone is increased by $90 \%$, compared to monthly mean ozone; this value is still higher than the ozone increase due to lightning reported by Fadnavis et al. (2015). Lightning is an additional source of tropospheric ozone, which is not included in the trajectory calculations neglecting chemistry employed here. However, in addition to lightning-produced $\mathrm{NO}_{x}$, ozone precursors likely uplifted by convection are necessary. Therefore, convective uplift is the basic transport mechanism for enhanced ozone in the middle and upper troposphere. Enhanced ozone measured over Lhasa is caused by uplift of ozone-rich air from the lower troposphere or produced by lightning; it is likely caused by a combination of both with a transport time from the planetary boundary layer to Lhasa of 20-30 days.

The ozone enhancement observed during the period 1820 August 2013 resulted from a tropopause fold and a stratospheric intrusion. The northern side of the Tibetan Plateau is a hotspot region for transport processes from the stratosphere to the troposphere, which are most likely due to tropopause fold events (Sprenger et al., 2003; Škerlak et al., 2014). These findings are corroborated by our case studies. Our results show that the stratospheric air masses characterized by high ozone, which are transported downward, are subsequently transported quasi-horizontally over large spatial scales in the ASM anticyclone. The stratospheric intrusion occurred over the southeastern edge of the ASM anticyclone and transported air equatorward with high ozone and low water vapour. Stratospheric intrusions contribute to high ozone and low water vapour values in the upper troposphere over Lhasa within the ASM anticyclone, thereby highlighting the important role of large-scale atmospheric dynamic transport for the trace gas budget in this region.

Satellite data and the trajectory calculations from the CLaMS model indicate that both the stratospheric intrusions and convective transport of air pollution play a major role in enhancing middle and upper tropospheric ozone over Lhasa, China. The PV values along the backward trajectories for the convective transport and the stratospheric intrusion are different and therefore a good indicator for the transport pathway of air masses. The PV values along the trajectories are less than 2 PVU for the convective transport case and greater than $6 \mathrm{PVU}$ for the stratospheric intrusion when air parcels originated in the extratropical lower stratosphere. The PV values decrease when air parcels cross the lapse-rate tropopause from the lower stratosphere to the troposphere. Tropical cyclones, which can transport marine boundary layer air with low ozone to the upper troposphere, lead to low ozone values in the upper troposphere in Lhasa (Li et al., 2017). The ozone variability in the middle and upper troposphere over Lhasa in 2013 is the result of different advective and convective transport processes transporting air parcels from different regions to Lhasa.

Our studies indicate that ozone variations in the UTLS over Lhasa are associated with a combination of processes, namely the intrusion of ozone-rich stratospheric air, the upward transport of low ozone concentrations in the marine boundary layer by tropical cyclones, and the uplift of polluted air rich in ozone in South Asia. Case studies are a first step to investigate and understand ozone variations within the ASM anticyclone; future work will focus on quantifying the long-term ozone and water variation in the UTLS within the ASM anticyclone, according to the 10-year balloon data from the SWOP campaign. Moreover, the SWOP campaigns will continue to be conducted for the next few years to extend the data set, thus allowing climatological studies to be conducted. 
Data availability. ERA-Interim meteorological reanalysis data are free available from the web page: http://apps.ecmwf.int/datasets/ data/interim-full-daily/ (last access: 3 November 2017). The OMI ozone data were downloaded from https://search.earthdata.nasa. gov/ (last access: 3 November 2017). The AIRS level-2 data used in this study can be obtained at https://airsl2.gesdisc.eosdis.nasa. gov/data/Aqua_AIRS_Level2/ (last access: 24 September 2018). The CloudSat products are provided on http://www.cloudsat. cira.colostate.edu (last access: 3 November 2017). The SWOP data of this paper are available upon request to Jianchun Bian (bjc@mail.iap.ac.cn). The CLaMS backward trajectories calculations can be requested from Dan Li (lidan@mail.iap.ac.cn).

Author contributions. DL wrote the first draft and produced all the figures. BV, RM, GG, and MR provided useful comments and revised the paper. JB and $\mathrm{HV}$ provided useful comments. JB, ZB, QL, $\mathrm{JZ}$, and DL made the balloon-borne measurements in Lhasa. HV supported for the measurements.

Competing interests. The authors declare that they have no conflict of interest.

Acknowledgements. Ozone and water vapour data are from the SWOP campaign, which is funded by the National Natural Science Foundation of China (41605025, 41675040, and 91637104). Our activities contribute to the European Community's Seventh Framework Programme (FP7/2007-2013) as part of the StratoClim project (grant agreement no. 603557). This work was supported by the International Postdoctoral Exchange Fellowship Program 2017 under grant no. 20171015 and the China Postdoctoral Science Foundation (2015M581153). Finally, we wish to thank two anonymous reviewers for very constructive suggestions.

The article processing charges for this open-access

publication were covered by a Research

Centre of the Helmholtz Association.

Edited by: Farahnaz Khosrawi

Reviewed by: two anonymous referees

\section{References}

Anderson, D. C., Nicely, J. M., Salawitch, R. J., Canty, T. P., Dickerson, R. R., Hanisco, T. F., Wolfe, G. M., Apel, E. C., Atlas, E., Bannan, T., Bauguitte, S., Blake, N. J., Bresch, J. F., Campos, T. L., Carpenter, L. J., Cohen, M. D., Evans, M., Fernandez, R. P., Kahn, B. H., Kinnison, D. E., Hall, S. R., Harris, N. R., Hornbrook, R. S., Lamarque, J.-F., Breton, M. L., Lee, J. D., Percival, C., Pfister, L., Pierce, R. B., Riemer, D. D., Saiz-Lopez, A., Stunder, B. J., Thompson, A. M., Ullmann, K., Vaughan, A., and Weinheimer, A. J.: A pervasive role for biomass burning in tropical high ozone/low water structures, Nat. Commun., 7, 10267, https://doi.org/10.1038/ncomms10267, 2016.

Aumann, H. H., Chahine, M. T., Gautier, C., Goldberg, M., Kalnay, E., McMillin, L., Revercomb, H., Rosenkranz, P. W., Smith,
W. L., Staelin, D., Strow, L., and Susskind, J.: AIRS/AMSU/HSB on the Aqua Mission: Design, Science Objectives, Data Products and Processing Systems, IEEE T. Geosci. Remote, 41, 253-264, 2003.

Bergman, J. W., Fierli, F., Jensen, E. J., Honomichl, S., and Pan, L. L.: Boundary layer sources for the Asian anticyclone: Regional contributions to a vertical conduit, J. Geophys. Res., 118, 2560-2575, https://doi.org/10.1002/jgrd.50142, 2013.

Bian, J. C., Pan, L. L., Paulik, L., Vömel, H., and Chen, H. B.: In situ water vapor and ozone measurements in Lhasa and Kunming during the Asian summer monsoon, Geophys. Res. Lett., 39, L19808, https://doi.org/10.1029/2012GL052996, 2012.

Brabec, M., Wienhold, F. G., Luo, B. P., Vömel, H., Immler, F., Steiner, P., Hausammann, E., Weers, U., and Peter, T.: Particle backscatter and relative humidity measured across cirrus clouds and comparison with microphysical cirrus modelling, Atmos. Chem. Phys., 12, 9135-9148, https://doi.org/10.5194/acp12-9135-2012, 2012.

Brunamonti, S., Jorge, T., Oelsner, P., Hanumanthu, S., Singh, B. B., Kumar, K. R., Sonbawne, S., Meier, S., Singh, D., Wienhold, F. G., Luo, B. P., Boettcher, M., Poltera, Y., Jauhiainen, H., Kayastha, R., Karmacharya, J., Dirksen, R., Naja, M., Rex, M., Fadnavis, S., and Peter, T.: Balloon-borne measurements of temperature, water vapor, ozone and aerosol backscatter on the southern slopes of the Himalayas during StratoClim 2016-2017, Atmos. Chem. Phys., 18, 15937-15957, https://doi.org/10.5194/acp-18-15937-2018, 2018.

Chen, B., Xu, X. D., Yang, S., and Zhao, T. L.: Climatological perspectives of air transport from atmospheric boundary layer to tropopause layer over Asian monsoon regions during boreal summer inferred from Lagrangian approach, Atmos. Chem. Phys., 12, 5827-5839, https://doi.org/10.5194/acp-125827-2012, 2012.

Cong, Z., Kawamura, K., Kang, S., and Fu, P.: Penetration of biomass-burning emissions from South Asia through the Himalayas: new insights from atmospheric organic acids, Sci. Rep., 5, 9580, https://doi.org/10.1038/srep09580, 2015.

Dee, D. P., Uppala, S. M., Simmons, A. J., Berrisford, P., Poli, P., Kobayashi, S., Andrae, U., Balmaseda, M. A., Balsamo, G., Bauer, P., Bechtold, P., Beljaars, A. C. M., van de Berg, L., Bidlot, J., Bormann, N., Delsol, C., Dragani, R., Fuentes, M., Geer, A. J., Haimberger, L., Healy, S. B., Hersbach, H., Hólm, E. V., Isaksen, L., Kållberg, P., Köhler, M., Matricardi, M., McNally, A. P., Monge-Sanz, B. M., Morcrette, J.-J., Park, B.-K., Peubey, C., de Rosnay, P., Tavolato, C., Thépaut, J.-N., and Vitart, F.: The ERA-Interim reanalysis: configuration and performance of the data assimilation system, Q. J. Roy. Meteor. Soc., 137, 553-597, https://doi.org/10.1002/qj.828, 2011.

Eisele, H., Scheel, H. E., Sladkovic, R., and Trickl, T.: High-resolution lidar measurements of stratosphere-troposphere exchange, J. Atmos. Sci., 56, 319-330, https://doi.org/10.1175/15200469(1999)056<0319:HRLMOS>2.0.CO;2, 1999.

Fadnavis, S. and Chattopadhyay, R.: Linkages of subtropical stratospheric intraseasonal intrusions with Indian summer monsoon deficit rainfall, J. Climate, 30, 5083-5095, https://doi.org/10.1175/JCLI-D-16-0463.1, 2017.

Fadnavis, S., Chakraborty, T., and Beig, G.: Seasonal stratospheric intrusion of ozone in the upper troposphere over India, Ann. Geo- 
phys., 28, 2149-2159, https://doi.org/10.5194/angeo-28-21492010, 2010.

Fadnavis, S., Semeniuk, K., Schultz, M. G., Kiefer, M., Mahajan, A., Pozzoli, L., and Sonbawane, S.: Transport pathways of peroxyacetyl nitrate in the upper troposphere and lower stratosphere from different monsoon systems during the summer monsoon season, Atmos. Chem. Phys., 15, 11477-11499, https://doi.org/10.5194/acp-15-11477-2015, 2015.

Fadnavis, S., Roy, C., Chattopadhyay, R., Sioris, C. E., Rap, A., Müller, R., Kumar, K. R., and Krishnan, R.: Transport of trace gases via eddy shedding from the Asian summer monsoon anticyclone and associated impacts on ozone heating rates, Atmos. Chem. Phys., 18, 11493-11506, https://doi.org/10.5194/acp-1811493-2018, 2018.

Fan, Q., Bian, J., and Pan, L. L.: Stratospheric entry point for upper-tropospheric air within the Asian summer monsoon anticyclone, Sci. China Earth Sci., 60, 1685-1693, https://doi.org/10.1007/s11430-016-9073-5, 2017a.

Fan, Q.-J., Bian, J.-C., and Pan, L. L.: Atmospheric boundary layer sources for upper tropospheric air over the Asian summer monsoon region, Atmos. Ocean. Sci. Lett., 10, 358-363, https://doi.org/10.1080/16742834.2017.1344089, 2017b.

Garny, H. and Randel, W. J.: Transport pathways from the Asian monsoon anticyclone to the stratosphere, Atmos. Chem. Phys., 16, 2703-2718, https://doi.org/10.5194/acp-16-27032016, 2016.

Gettelman, A., Hoor, P., Pan, L. L., Randel, W. J., Hegglin, M. I., and Birner, T.: The extratropical upper troposphere and lower stratosphere, Rev. Geophys., 49, RG3003, https://doi.org/10.1029/2011RG000355, 2011.

Goff, J. A. and Gratch, S.: Low-pressure properties of water from -160 to 212 F, Trans. Am. Soc. Heating Air-Cond. Eng., 52, 95-122, 1946.

Gottschaldt, K.-D., Schlager, H., Baumann, R., Cai, D. S., Eyring, V., Graf, P., Grewe, V., Jöckel, P., Jurkat-Witschas, T., Voigt, C., Zahn, A., and Ziereis, H.: Dynamics and composition of the Asian summer monsoon anticyclone, Atmos. Chem. Phys., 18, 5655-5675, https://doi.org/10.5194/acp-18-5655-2018, 2018.

Gu, Y., Liao, H., and Bian, J.: Summertime nitrate aerosol in the upper troposphere and lower stratosphere over the Tibetan Plateau and the South Asian summer monsoon region, Atmos. Chem. Phys., 16, 6641-6663, https://doi.org/10.5194/acp-166641-2016, 2016.

Holton, J. R., Haynes, P., McIntyre, M. E., Douglass, A. R., Rood, R. B., and Pfister, L.: Stratosphere-troposphere exchange, Rev. Geophys., 33, 403-439, 1995.

Hoor, P., Wernli, H., Hegglin, M. I., and Bönisch, H.: Transport timescales and tracer properties in the extratropical UTLS, Atmos. Chem. Phys., 10, 7929-7944, https://doi.org/10.5194/acp10-7929-2010, 2010.

Hoskins, B. J. and Rodwell, M. J.: A model of the Asian summer monsoon. Part I: The global scale, J. Atmos. Sci., 52, 1329-1340, 1995.

Hyland, R. W. and Wexler, A.: Formulations for the thermodynamic properties of the saturated phases of $\mathrm{H}_{2} \mathrm{O}$ from $173.15 \mathrm{~K}$ to 473.15 K, ASHRAE Trans., 89, 500-519, 1983.

Kita, K., Kawakami, S., Miyazaki, Y., Higashi, Y., Kondo, Y., Nishi, N., Koike, M., Blake, D. R., Machida, T., Sano, T., Hu, W., Ko, M., and Ogawa, T.: Photochemical production of ozone in the upper troposphere in association with cumulus convection over Indonesia, J. Geophys. Res., 107, 8400, https://doi.org/10.1029/2001JD000844, 2002.

Koch, P., Wernli, H., and Davies, H. C.: An event-based jetstream climatology and typology, Int. J. Climatol., 26, 283-301, https://doi.org/10.1002/joc.1255, 2006.

Komhyr, W. D., Barnes, R. A., Brothers, G. B., Lathrop, J. A., and Opperman, D. P.: Electrochemical concentration cell ozonesonde performance evaluation during STOIC 1989, J. Geophys. Res., 100, 9231-9244, https://doi.org/10.1029/94JD02175, 1995.

Konopka, P., Steinhorst, H.-M., Grooß, J.-U., Günther, G., Müller, R., Elkins, J. W., Jost, H.-J., Richard, E., Schmidt, U., Toon, G., and McKenna, D. S.: Mixing and Ozone Loss in the 1999-2000 Arctic Vortex: Simulations with the 3-dimensional Chemical Lagrangian Model of the Stratosphere (CLaMS), J. Geophys. Res., 109, D02315, https://doi.org/10.1029/2003JD003792, 2004.

Konopka, P., Günther, G., Müller, R., dos Santos, F. H. S., Schiller, C., Ravegnani, F., Ulanovsky, A., Schlager, H., Volk, C. M., Viciani, S., Pan, L. L., McKenna, D.-S., and Riese, M.: Contribution of mixing to upward transport across the tropical tropopause layer (TTL), Atmos. Chem. Phys., 7, 3285-3308, https://doi.org/10.5194/acp-7-3285-2007, 2007.

Kuang, S., Newchurch, M. J., Burris, J., Wang, L., Knupp, K., and Huang, G.: Stratosphere to troposphere transport revealed by ground-based lidar and ozonesonde at a midlatitude site, J. Geophys. Res., 117, D18305, https://doi.org/10.1029/2012JD017695, 2012.

Langford, A. O., Masters, C. D., Proffitt, M. H., Hsie, E.-Y., and Tuck, A. F.: Ozone measurements in a tropopause fold associated with a cut-off system, Geophys. Res. Lett., 23, 2501-2504, https://doi.org/10.1029/96GL02227, 1996.

Langford, A. O., Pierce, R. B., and Schultz, P. J.: Stratospheric intrusions, the Santa Ana winds, and wildland fires in Southern California, Geophys. Res. Lett., 42, 6091-6097, https://doi.org/10.1002/2015GL064964, 2015.

Levelt, P. F., Van den Oord, G. H. J., Dobber, M. R., Mälkki, A., Visser, H., de Vries, J., Stammes, P., Lundell, J. O. V., and Saari, H.: The ozone monitoring instrument, IEEE T. Geophys. Remote, 44, 1093-1101, https://doi.org/10.1109/TGRS.2006.872333, 2006.

Li, D. and Bian, J.: Observation of a Summer Tropopause Fold by Ozonesonde at Changchun, China: Comparison with Reanalysis and Model Simulation, Adv. Atmos. Sci., 32, 1354-1364, https://doi.org/10.1007/s00376-015-5022-x, 2015.

Li, D., Vogel, B., Bian, J., Müller, R., Pan, L. L., Günther, G., Bai, Z., Li, Q., Zhang, J., Fan, Q., and Vömel, H.: Impact of typhoons on the composition of the upper troposphere within the Asian summer monsoon anticyclone: the SWOP campaign in Lhasa 2013, Atmos. Chem. Phys., 17, 4657-4672, https://doi.org/10.5194/acp-17-4657-2017, 2017.

Lin, M., Fiore, A. M., Horowitz, L. W., Langford, A. O., Oltmans, S. J., Tarasick, D., and Rieder, H. E.: Climate variability modulates western US ozone air quality in spring via deep stratospheric intrusions, Nat. Commun., 6, 7105, https://doi.org/10.1038/ncomms8105, 2015.

Marchand, R., Mace, G. G., Ackerman, T., and Stephens, G.: Hydrometeor Detection Using Cloudsat-An Earth-Orbiting 94GHz Cloud Radar, J. Atmos. Ocean. Tech., 25, 519-533, https://doi.org/10.1175/2007JTECHA1006.1, 2008. 
Mason, B. R. and Anderson, E. C.: The development and decay of the 100-mb. summertime anticyclone over southern Asia, Mon. Weather Rev., 91, 3-12, https://doi.org/10.1175/15200493(1963)091<0003:TDADOT>2.3.CO;2, 1963.

McKenna, D. S., Konopka, P., Grooß, J.-U., Günther, G., Müller, R., Spang, R., Offermann, D., and Orsolini, Y.: A new Chemical Lagrangian Model of the Stratosphere (CLaMS): 1. Formulation of advection and mixing, J. Geophys. Res., 107, 4309, https://doi.org/10.1029/2000JD000114, 2002.

Myhre, G., Shindell, D., Bréon, F.-M., Collins, W., Fuglestvedt, J., Huang, J., Koch, D., Lamarque, J.-F., Lee, D., Mendoza, B., Nakajima, T., Robock, A., Stephens, G., Takemura, T., and Zhang, H.: Anthropogenic and Natural Radiative Forcing, in: Climate Change 2013: The Physical Science Basis. Contribution of Working Group I to the Fifth Assessment Report of the Intergovernmental Panel on Climate Change, edited by: Stocker, T. F., Qin, D., Plattner, G.-K., Tignor, M., Allen, S. K., Boschung, J., Nauels, A., Xia, Y., Bex, V., and Midgley, P. M., Cambridge University Press, Cambridge, UK and New York, NY, USA, https://doi.org/10.1017/CBO9781107415324.018, 2013.

Ojha, N., Naja, M., Sarangi, T., Kumar, R., Bhardwaj, P., Lal, S., Venkataramani, S., Sagar, R., Kumar, A., and Chandola, H.: On the processes influencing the vertical distribution of ozone over the central Himalayas: Analysis of yearlong ozonesonde observations, Atmos. Environ., 88, 201-211, https://doi.org/10.1016/j.atmosenv.2014.01.031, 2014.

Ojha, N., Pozzer, A., Akritidis, D., and Lelieveld, J.: Secondary ozone peaks in the troposphere over the Himalayas, Atmos. Chem. Phys., 17, 6743-6757, https://doi.org/10.5194/acp-176743-2017, 2017.

Olsen, E. T. (Ed.): AIRS/AMSU/HSB Version 6 Level 2 Product User Guide, Jet Propulsion Laboratory, California Institute of Technology, Pasadena, CA, USA, 2017.

Pan, L. L., Honomichl, S. B., Kinnison, D. E., Abalos, M., Randel, W. J., Bergman, J. W., and Bian, J. C.: Transport of chemical tracers from the boundary layer to stratosphere associated with the dynamics of the Asian summer monsoon, J. Geophys. Res.-Atmos., 121, 14159-14174, https://doi.org/10.1002/2016JD025616, 2016.

Park, M., Randel, W. J., Emmons, L. K., and Livesey, N. J.: Transport pathways of carbon monoxide in the Asian summer monsoon diagnosed from Model of Ozone and Related Tracers (MOZART), J. Geophys. Res., 114, D08303, https://doi.org/10.1029/2008JD010621, 2009.

Ploeger, F., Konopka, P., Günther, G., Grooß, J.-U., and Müller, R.: Impact of the vertical velocity scheme on modeling transport across the tropical tropopause layer, J. Geophys. Res., 115, D03301, https://doi.org/10.1029/2009JD012023, 2010.

Ploeger, F., Gottschling, C., Griessbach, S., Grooß, J.-U., Guenther, G., Konopka, P., Müller, R., Riese, M., Stroh, F., Tao, M., Ungermann, J., Vogel, B., and von Hobe, M.: A potential vorticitybased determination of the transport barrier in the Asian summer monsoon anticyclone, Atmos. Chem. Phys., 15, 13145-13159, https://doi.org/10.5194/acp-15-13145-2015, 2015.

Pommrich, R., Müller, R., Grooß, J.-U., Konopka, P., Ploeger, F., Vogel, B., Tao, M., Hoppe, C. M., Günther, G., Spelten, N., Hoffmann, L., Pumphrey, H.-C., Viciani, S., D’Amato, F., Volk, C. M., Hoor, P., Schlager, H., and Riese, M.: Tropical troposphere to stratosphere transport of carbon monoxide and long-lived trace species in the Chemical Lagrangian Model of the Stratosphere (CLaMS), Geosci. Model Dev., 7, 2895-2916, https://doi.org/10.5194/gmd-7-2895-2014, 2014.

Qie, X. S., Wu, X. K., Yuan, T., Bian, J. C., and Lü, D. R.: Comprehensive Pattern of Deep Convective Systems over the Tibetan Plateau-South Asian Monsoon Region Based on TRMM Data, J. Climate, 27, 6612-6626, https://doi.org/10.1175/JCLI-D-14$00076.1,2014$

Randel, W. J., Park, M., Emmons, L., Kinnison, D., Bernath, P., Walker, K. A., Boone, C., and Pumphrey, H.: Asian Monsoon Transport of Pollution to the Stratosphere, Science, 328, 611613, https://doi.org/10.1126/science.1182274, 2010.

Riese, M., Ploeger, F., Rap, A., Vogel, B., Konopka, P., Dameris, M., and Forster, P.: Impact of uncertainties in atmospheric mixing on simulated UTLS composition and related radiative effects, J. Geophys. Res., 117, D16305, https://doi.org/10.1029/2012JD017751, 2012.

Rosen, J. M. and Kjome, N. T.: Backscattersonde: a new instrument for atmospheric aerosol research, Appl. Optics, 30, 1552-1561, https://doi.org/10.1029/97JD01486, 1991.

Schumann, U. and Huntrieser, H.: The global lightning-induced nitrogen oxides source, Atmos. Chem. Phys., 7, 3823-3907, https://doi.org/10.5194/acp-7-3823-2007, 2007.

Škerlak, B., Sprenger, M., and Wernli, H.: A global climatology of stratosphere-troposphere exchange using the ERA-Interim data set from 1979 to 2011, Atmos. Chem. Phys., 14, 913-937, https://doi.org/10.5194/acp-14-913-2014, 2014.

Song, Y., Lü, D., Li, Q., Bian, J., Wu, X., and Li, D.: The impact of cut-off lows on ozone in the upper troposphere and lower stratosphere over Changchun from ozonesonde observations, Adv. Atmos. Sci., 33, 135-150, https://doi.org/10.1007/s00376-0155054-2, 2016.

Sprenger, M., Maspoli, M. C., and Wernli, H.: Tropopause folds and cross-tropopause exchange: A global investigation based upon ECMWF analyses for the time period March 2000 to February 2001, J. Geophys. Res., 108, 8518, https://doi.org/10.1029/2002JD002587, 2003.

Stevenson, D. S., Young, P. J., Naik, V., Lamarque, J.-F., Shindell, D. T., Voulgarakis, A., Skeie, R. B., Dalsoren, S. B., Myhre, G., Berntsen, T. K., Folberth, G. A., Rumbold, S. T., Collins, W. J., MacKenzie, I. A., Doherty, R. M., Zeng, G., van Noije, T. P. C., Strunk, A., Bergmann, D., Cameron-Smith, P., Plummer, D. A., Strode, S. A., Horowitz, L., Lee, Y. H., Szopa, S., Sudo, K., Nagashima, T., Josse, B., Cionni, I., Righi, M., Eyring, V., Conley, A., Bowman, K. W., Wild, O., and Archibald, A.: Tropospheric ozone changes, radiative forcing and attribution to emissions in the Atmospheric Chemistry and Climate Model Intercomparison Project (ACCMIP), Atmos. Chem. Phys., 13, 3063-3085, https://doi.org/10.5194/acp-13-3063-2013, 2013.

Stohl, A. and Trickl, T.: A textbook example of long-range transport: Simultaneous observation of ozone maxima of stratospheric and North American origin in the free troposphere over Europe, J. Geophys. Res., 104, 30445-30462, https://doi.org/10.1029/1999JD900803, 1999.

Stohl, A., Bonasoni, P., Cristofanelli, P., Collins, W., Feichter, J., Frank, A., Forster, C., Gerasopoulos, E., Gäggeler, H., James, P., Kentarchos, T., Kromp-Kolb, H., Krüger, B., Land, C., Meloen, J., Papayannis, A., Priller, A., Seibert, P., Sprenger, M., Roelofs, G. J., Scheel, H. E., Schnabel, C., Siegmund, P., To- 
bler, L., Trickl, T., Wernli, H., Wirth, V., Zanis, P., and Zerefos, C.: Stratosphere-troposphere exchange: A review, and what we have learned from STACCATO, J. Geophys. Res., 108, 8516, https://doi.org/10.1029/2002JD002490, 2003.

Tao, M., Pan, L. L., Konopka, P., Honomichl, S. B., Kinnison, D. E., and Apel, E. C.: A Lagrangian Model Diagnosis of Stratospheric Contributions to Tropical Midtropospheric Air, J. Geophys. Res., 123, 9764-9785, https://doi.org/10.1029/2018JD028696, 2018.

Tissier, A.-S. and Legras, B.: Convective sources of trajectories traversing the tropical tropopause layer, Atmos. Chem. Phys., 16, 3383-3398, https://doi.org/10.5194/acp-16-3383-2016, 2016.

Trickl, T., Feldmann, H., Kanter, H.-J., Scheel, H.-E., Sprenger, M., Stohl, A., and Wernli, H.: Forecasted deep stratospheric intrusions over Central Europe: case studies and climatologies, Atmos. Chem. Phys., 10, 499-524, https://doi.org/10.5194/acp-10499-2010, 2010.

Trickl, T., Bärtsch-Ritter, N., Eisele, H., Furger, M., Mücke, R., Sprenger, M., and Stohl, A.: High-ozone layers in the middle and upper troposphere above Central Europe: potential import from the stratosphere along the subtropical jet stream, Atmos. Chem. Phys., 11, 9343-9366, https://doi.org/10.5194/acp11-9343-2011, 2011.

Trickl, T., Vogelmann, H., Giehl, H., Scheel, H.-E., Sprenger, M., and Stohl, A.: How stratospheric are deep stratospheric intrusions?, Atmos. Chem. Phys., 14, 9941-9961, https://doi.org/10.5194/acp-14-9941-2014, 2014.

Vernier, J. P., Fairlie, T. D., Natarajan, M., Wienhold, F. G., Bian, J., Martinsson, B. G., Crumeyrolle, S., Thomason, L. W., and Bedka, K. M.: Increase in upper tropospheric and lower stratospheric aerosol levels and its potential connection with Asian pollution, J. Geophys. Res.-Atmos., 120, 1608-1619, https://doi.org/10.1002/2014JD022372, 2015.

Vernier, J.-P., Fairlie, T. D., Deshler, T., Ratnam, M. V., Gadhavi, H., Kumar, B. S., Natarajan, M., Pandit, A. K., Raj, S. T. A., Kumar, A. H., Jayaraman, A., Singh, A. K., Rastogi, N., Sinha, P. R., Kumar, S., Tiwari, S., Wegner, T., Baker, N., Vignelles, D., Stenchikov, G., Shevchenko, I., Smith, J., Bedka, K., Kesarkar, A., Singh, V., Bhate, J., Ravikiran, V., Rao, M. D., Ravindrababu, S., Patel, A., Vernier, H., Wienhold, F. G., Liu, H., Knepp, T. N., Thomason, L., Crawford, J., Ziemba, L., Moore, J., Crumeyrolle, S., Williamson, M., Berthet, G., Jégou, F., and Renard, J.B.: BATAL: The balloon measurement campaigns of the Asian tropopause aerosol layer, B. Am. Meteorol. Soc., 99, 955-973, https://doi.org/10.1175/BAMS-D-17-0014.1, 2018.

Vogel, B., Pan, L. L., Konopka, P., Günther, G., Müller, R., Hall, W., Campos, T., Pollack, I., Weinheimer, A., Wei, J., Atlas, E. L., and Bowman, K. P.: Transport pathways and signatures of mixing in the extratropical tropopause region derived from Lagrangian model simulations, J. Geophys. Res., 116, D05306, https://doi.org/10.1029/2010JD014876, 2011.

Vogel, B., Günther, G., Müller, R., Grooß, J.-U., Hoor, P., Krämer, M., Müller, S., Zahn, A., and Riese, M.: Fast transport from Southeast Asia boundary layer sources to northern Europe: rapid uplift in typhoons and eastward eddy shedding of the Asian monsoon anticyclone, Atmos. Chem. Phys., 14, 12745-12762, https://doi.org/10.5194/acp-14-12745-2014, 2014.
Vogel, B., Günther, G., Müller, R., Grooß, J.-U., and Riese, M.: Impact of different Asian source regions on the composition of the Asian monsoon anticyclone and of the extratropical lowermost stratosphere, Atmos. Chem. Phys., 15, 13699-13716, https://doi.org/10.5194/acp-15-13699-2015, 2015.

Vogel, B., Günther, G., Müller, R., Grooß, J.-U., Afchine, A., Bozem, H., Hoor, P., Krämer, M., Müller, S., Riese, M., Rolf, C., Spelten, N., Stiller, G. P., Ungermann, J., and Zahn, A.: Longrange transport pathways of tropospheric source gases originating in Asia into the northern lower stratosphere during the Asian monsoon season 2012, Atmos. Chem. Phys., 16, 15301-15325, https://doi.org/10.5194/acp-16-15301-2016, 2016.

Vogel, B., Müller, R., Günther, G., Spang, R., Hanumanthu, S., Li, D., Riese, M., and Stiller, G. P.: Lagrangian simulations of the transport of young air masses to the top of the Asian monsoon anticyclone and into the tropical pipe, Atmos. Chem. Phys. Discuss., https://doi.org/10.5194/acp-2018-724, in review, 2018.

Vömel, H., David, D. E., and Smith, K.: Accuracy of tropospheric and stratospheric water vapor measurements by the cryogenic frost point hygrometer: Instrumental details and observations, J. Geophys. Res., 112, D08305, https://doi.org/10.1029/2006JD007224, 2007.

Vömel, H., Naebert, T., Dirksen, R., and Sommer, M.: An update on the uncertainties of water vapor measurements using cryogenic frost point hygrometers, Atmos. Meas. Tech., 9, 37553768, https://doi.org/10.5194/amt-9-3755-2016, 2016.

Weigel, K., Hoffmann, L., Günther, G., Khosrawi, F., Olschewski, F., Preusse, P., Spang, R., Stroh, F., and Riese, M.: A stratospheric intrusion at the subtropical jet over the Mediterranean Sea: air-borne remote sensing observations and model results, Atmos. Chem. Phys., 12, 8423-8438, https://doi.org/10.5194/acp-12-8423-2012, 2012.

WMO: Definition of the tropopause, WMO Bull, IV (4), WMO, Geneva, Switzerland, 134-138, 1957.

Yan, R. C. and Bian, J. C.: Tracing the boundary layer sources of carbon monoxide in the Asian summer monsoon anticyclone using WRF-Chem, Adv. Atmos. Sci., 32, 943-951, https://doi.org/10.1007/s00376-014-4130-3, 2015.

Yang, H., Chen, G., Tang, Q., and Hess, P.: Quantifying isentropic stratosphere-troposphere exchange of ozone, J. Geophys. Res.-Atmos., 121, 3372-3387, https://doi.org/10.1002/2015JD024180, 2016.

Yu, P., Rosenlof, K. H., Liu, S., Telg, H., Thornberry, T. D., Rollins, A. W., Portmann, R. W., Bai, Z., Ray, E. A., Duan, Y., Pan, L. L., Toon, O. B., Bian, J., and Gao, R.-S.: Efficient transport of tropospheric aerosol into the stratosphere via the Asian summer monsoon anticyclone, P. Natl. Acad. Sci. USA, 114, 6972-6977, https://doi.org/10.1073/pnas.1701170114, 2017. 